\title{
Investigating treatment windows for effective and environmentally sound herbicide applications for controlling tree- of-heaven
}

William E. Eck

West Virginia University

Follow this and additional works at: https://researchrepository.wvu.edu/etd

\section{Recommended Citation}

Eck, William E., "Investigating treatment windows for effective and environmentally sound herbicide applications for controlling tree-of-heaven" (2005). Graduate Theses, Dissertations, and Problem Reports. 4145.

https://researchrepository.wvu.edu/etd/4145

This Thesis is protected by copyright and/or related rights. It has been brought to you by the The Research Repository @WVU with permission from the rights-holder(s). You are free to use this Thesis in any way that is permitted by the copyright and related rights legislation that applies to your use. For other uses you must obtain permission from the rights-holder(s) directly, unless additional rights are indicated by a Creative Commons license in the record and/ or on the work itself. This Thesis has been accepted for inclusion in WVU Graduate Theses, Dissertations, and Problem Reports collection by an authorized administrator of The Research Repository @ WVU. For more information, please contact researchrepository@mail.wvu.edu. 


\title{
Investigating Treatment Windows for Effective and Environmentally Sound Herbicide Applications for Controlling Tree-of-Heaven
}

\author{
William E. Eck \\ Thesis submitted to the \\ Davis College of Agriculture, Forestry, and Consumer Sciences \\ at West Virginia University \\ in partial fulfillment of the requirements \\ for the degree of \\ Master of Science \\ in \\ Forest Resources Management
}

David W. McGill, Ph.D., Chair

John R. Brooks, Ph.D.

William N. Grafton, Ph.D.

Division of Forestry

Morgantown, WV

2005

Keywords: Tree-of-heaven, Ailanthus, invasive, herbicide, triclopyr, imazapyr 


\title{
Abstract \\ Investigating Treatment Windows for Effective and Environmentally Sound Herbicide Applications for Controlling Tree-of-Heaven
}

\begin{abstract}
William E. Eck
This paper discusses three research studies, each investigating a different treatment window for controlling tree-of-heaven using effective and environmentally sound herbicide applications. In the first study, efficacy of the herbicides triclopyr and imazapyr was tested using injection and basal bark treatment methods. In the second study, efficacy of triclopyr with different levels of imazapyr was tested using the basal bark treatment method. In the third study, weekly timing of chemical controls was investigated. Our study yielded a recommendation to treat tree-of-heaven with a low volume basal spray of Garlon 4 in a non-aromatic penetrating oil when growth is maximized in early summer (June 1-July 12), following a period of at least average precipitation. Treatments with imazapyr damaged untreated neighbor stems, probably through root connections and/or root leaking, so use of this chemical is not recommended near high value timber trees.
\end{abstract}




\section{Table of Contents}

ABSTRACT

ii

LITERATURE REVIEW

$-1-$

History OF A. ALTISSIMA

SILVICS

RANGE

SITE

PATHOGENS

REPRODUCTION AND PROPAGATION

$-3-$

PALATABILITY

ALLELOPATHY

AS AN INVADER

USES OF A. ALTISSIMA

PROBLEMS ASSOCIATED WITH A. ALTISSIMA

CONTROLS

REFERENCES

-3 -

$-6-$

-7 -

-7 -

-10 -

-10 -

- 11 -

-12 -

- 13 -

- 14 -

- 16 -

-17 -

- 20 -

CHAPTER 1. TESTING THE EFFICACY OF TRICLOPYR AND IMAZAPYR USING TWO APPLICATION METHODS FOR CONTROLLING TREE-OF-HEAVEN ALONG A WEST VIRGINIA HIGHWAY

ABSTRACT

$-26-$

INTRODUCTION

-26 -

METHODS

$-27-$

STUDY SITE

$-27-$

HERBICIDE TREATMENTS AND APPLICATION METHODS

$-28-$

TREATMENT TREES AND ASSOCIATED VEGETATION

$-29-$

NUMERICAL METHODS

$-30-$

RESULTS AND DISCUSSION

-30 -

MANAGEMENT IMPLICATIONS

REFERENCES

$-34-$

-34 -

CHAPTER 2. DETERMINING THE MINIMUM IMAZAPYR LEVEL EFFECTIVE IN CONTROL OF TREE-OF-HEAVEN ALONG A WEST VIRGINIA HIGHWAY $-36-$

INTRODUCTION

$-36-$ METHODS

-38 -

HERBICIDES

$-38-$

TREATMENTS AND ASSESMENT

$-38-$

RESULTS AND DISCUSSION

-40 -

MANAGEMENT IMPLICATIONS

-43 -

REFERENCES

-43 - 
INTRODUCTION

METHODS

STUDY SITE

VEGETATION SAMPLING

HERBICIDE TREATMENTS

NUMERICAL METHODS

RESULTS

SEASONAL GROWTH PATTERNS OF TREE-OF-HEAVEN

-45 -

-48 -

$-48-$

$-48-$

$-49-$

$-50-$

-50 -

EFFECTS OF TIMING ON EFFICACY OF BASAL BARK TREATMENTS

$-51-$

DISCUSSION

$-51-$

MANAGEMENT IMPLICATIONS

$-52-$

AKNOWLEDGEMENTS

REFERENCES

$-54-$

-54 -

-55 - 


\section{Literature Review}

To begin a discussion of a non-native invasive plant such as Ailanthus altissima (Mill.) Swingle, it is important to start by defining some of the basic terminology associated with this topic, as many terms and phrases are used interchangeably (i.e. non-indigenous, non-native, alien, exotic, etc.) and some terms have multiple definitions.

A widely cited definition of an invasive species is that given by Executive Order 13112 (1999) which defines invasive species as: "alien species whose introduction does or is likely to cause economic or environmental harm or harm to human health." Invasive plants have also been defined as those that can establish themselves in relatively undisturbed natural communities (Huenneke et al., 1990). For the purposes of this literature review, an invasive plant is one that has the ability to become established in a new environment where it can propagate, spread, and remain, to the detriment of the surrounding habitat.

Although the preponderance of literature on invasive species deals with non-native invasives, not all are non-native. Often, the most invasive plants are native, as in the case of black locust (Robinia pseudoacacia L.)(Uva et al., 1997), hay scented fern (Dennstaedtia punctilobula (Michx.)M. Moore (de la Cretza and Kelty, 1999), and goldenrods (Solidago canadensis L. and Solidago altissima L.) (Whitson 1996; Uva et al., 1997). In fact, Uva et al. (1997), list 84 native invasive species in the northeastern U.S. and Whitson (1996) lists 121 in the West.

Biological invasions are the leading causes of recent extinction (over the last 400 years), and one of the main causes of endangerment of species, second only to habitat destruction 
(Vitousek et al., 1997). They have been shown to increase carbon assimilation rates (Le Maitre et al., 1996), change soil nutrient status (Vitousek and Walker, 1989), increase flammability (Anable et al., 1992), threaten native species (Musil 1993; Meyer and Florence 1996), change habitat suitability for native animal species (Steenkamp and Chown 1996; Allan et al., 1997), and bring about substantial negative economic consequences (Higgins et al., 1999). A growing body of work shows that non-indigenous invasive species decrease native biodiversity and alter ecosystem functioning (Vitousek and Walker 1989; D'Antonio and Vitousek, 1992; Schmitz et al., 1997; Walker and Steffen, 1997; Parker and Reichard, 1998).

According to the U.S. Congress, Office of Technology Assessment (1993), it is estimated that there are over 2,000 species of non-native invasive plants in the US, a substantial portion of which cause significant economic and ecological damage. It is well known that many invasive species can spread over large areas and threaten ecosystems, yet plant introductions continue at an alarming rate (Rejmanek and Randall 1994). The 1993 report of the Office of Technology Assessment stated that "Although much information on non-indigenous species exists, overall it is widely scattered, sometimes obscure, and highly variable on quality and scientific rigor."

The tree-of-heaven is a non-native invasive plant that threatens natural flora and fauna (Call and Nilson 2003). Invasive plants have competitive traits that exceed those found in natural communities resulting in their dominance over native plant species (Callaway and Aschehoug 2000). Invasive species such as tree-of-heaven can also render native plants extinct, leading to a decrease in regional biodiversity (D'Antonio and Vitousek 1992) and altered ecosystem processes (Vitousek and Walker 1989). 
The literature on tree-of-heaven is relatively scant when compared with other North American forest tree species, but there is no shortage of hearsay, misrepresentation, and local opinion about the species and its realized and potential uses (Bryant, 1973; Feret, 1985).

\section{History of A. altissima}

Ailanthus altissima is also known by many common names including, but not limited to, tree-of-heaven, tree of sun, Persian sumac, Chinese sumac, heavenwood, stinking chun, smoke tree, stink tree, copal tree, ailanthus, Brooklyn palm, and stinking sumac. The generic name Ailanthus, as well as the common name tree-of-heaven, likely comes from the East Indian (Mollucan) word "Aylanto" which means heaven tree and refers to the height of the native species A. moluccana (Siren, 1916; Little, 1979). Guerin-Manville (1862) states that because of its outstanding virtues, the tree was called "blessed tree of God" in France giving the common name, tree-of-heaven.

The native range of Ailanthus altissima is disputed. Many believe it originated in a relatively small area of eastern Asia (Little, 1979), but many others extend it east into Japan, as far south as Malaysia (Balero et al., 2003), and west to Pakistan (Ashraf and Sham-ur-Rehman, 2001). Others believe that populations found in Japan and elsewhere may have become naturalized after early introductions (Feret, 1985). According to the Chinese literature, tree-ofheaven is native to the lower Yangtze (Chang-Jiang; in provinces Hubei, Henan, Anhui, Jingsu, Hunan, Jingxi and Zhejiang) and Korea (Udvardy, 1998).

The first record of this species in the West is in 1751 when it was first grown in Europe from seeds sent from Nanjing by a French Jesuit priest, Pierre Nicholas d'Incarville (Dillwyn, 1843). William Hamilton, a plant collector and landscape improver from Philadelphia, brought it to the United States in 1784 along with other Asian plants such as Ginkgo biloba L. (Shah, 
1997). A second importation of seed was made from England in 1790 by a Long Island plantsman, William Prince, who planted the trees in Flushing, NY (Davies, 1942). In these times it was often confused with Chinese varnish tree, Toxicodendron verniciflua (Stokes) F. Barkley, or thought to be a new species of sumac. It was given its own generic status in 1786 (Swingle, 1916). Tree-of-heaven may have also been introduced into western America in the 1800 's by Chinese miners as they settled in California (Hoshovsky, 1988).

In 1841, A.J. Downing wrote in A Treatise on the Theory and Practice of Landscape Gardening, that Ailanthus was "one of the commonest trees sold in the nurseries," and "it is a picturesque tree, well adapted to produce a good effect on the lawn singly, or grouped." In 1847, Downing wrote in The Horticulturist that whole rows of European Linden trees were being cut down because they were infested with odious worms and that "on this account, that foreign tree, the Ailanthus, the strong scented foliage of which no insect will attack, every day becoming a greater metropolitan favorite."

In July of 1852, Downing again editorialized about Ailanthus, reproving readers for planting "odorous Ailanthuses and filthy poplars, to the neglect of graceful elms and salubrious maples." The next month his opinion of the once loved tree had further deteriorated; he wrote, 'Down with the Ailanthus! This 'tree-of-heaven,' (as the catalogues used alluringly to call it,) has penetrated all parts of the union, and begins to show its true character." He also puts forward that Ailanthus was "an usurper in rather bad odor at home, which has come over to this land of liberty, under the garb of utility to make foul the air, with its pestilent breath, and devour the soil with its intermeddling roots." 1

\footnotetext{
${ }^{1}$ A Treatise on the Theory and Practice of Landscape Gardening continued to carry Downing's original, favorable report of Ailanthus despite his changed opinion. In the $7^{\text {th }}$ edition in 1865, edited and supplemented by H.W. Sargent, a footnote acknowledges the changed opinion and suggests that the tree-of-heaven can be replaced by the princess tree (Paulownia tomentosa) (Shah, 1997)
} 
Many American came to see things Downing's way and many trees were uprooted and discarded, but not everyone shared Downing's opinion. In her 1943 novel, A Tree Grows in Brooklyn, Betty Smith wrote:

\footnotetext{
"There's a tree that grows in Brooklyn. Some people call it the Tree-of-heaven. No matter where its seed falls, it makes a tree which struggles to reach the sky. It grows in boarded-up lots and out of neglected rubbish heaps. It grows up out of cellar gratings. It is the only tree that grows out of cement. It grows lushly ... survives without sun, water, and seemingly earth."
}

Opinion about Ailanthus has remained divided in this country. Some thought it could still be useful with an 1874 issue of The Horticulturist giving direction for preparing a dysentery treatment from its rootbark. While reports of its usefulness in curing one ailment were being noted, others noted problems arising from the tree's pollen, with many people developing allergic reaction with hay fever symptoms lasting a few weeks. One report claimed more serious symptoms with chronic sore throats, disturbed stomachs, and nausea, and finally over time, tuberculosis. As a result, several states and the District of Columbia barred cultivation of Ailanthus (Shah, 1997). Charles Sprague Sargent wrote in 1888 that it was used as a scapegoat for other urban conditions that may have caused the illness and that its usefulness should be reconsidered (Tice, 1888). Despite published gainsay of this species, it continued to be planted in many urban greenways. Samuel Parsons, Jr. noted in 1892 that A. altissima is "in some respects the toughest and finest of trees," and specified this species for a significant percentage of trees when he drew up plans for the extension of the New York East River Park (Parsons, 1915).

C.S. Sargent and his uncle H.H. Hunnewell commissioned nurseries to plant $A$. altissima to evaluate the tree's usefulness in timber for uses in furniture, railroad ties, and 
fuel (Douglas, 1882; Meehan, 1885; Sargent, 1888). These efforts failed and by the 1920's A. altissima was no longer used in the United States and has since been neglected and allowed to spread on its own. In some locations, Ailanthus altissima is so common that it appears to be a part of the native flora (Little, 1979).

Although A. altissima is known to be an exotic species, there is evidence that the genre Ailanthus was present in North America at some earlier time in history. Ecocene fossils of Ailanthus spp. have been found in the Green River Valley of Wyoming (Brown, 1941).

Two closely related species to tree-of-heaven are recognized by Rehder (1954). $A$. giraldi Dode and A. vilmoriana Dode were introduced from western China in 1897 as well as the variety A. giraldi var. Duclouxii Dode.(Rehder 1954). It is not clear whether these species are actually racial variations of A. altissima or are true species. Any mention of Ailanthus in this paper will refer to Ailanthus altissima.

\section{Silvics}

Fralish (2002) gives a good description of this plant's physical features. He describes it as a small to medium-sized tree. The deciduous pinnately compound leaves are arranged alternately and grow $45-60 \mathrm{~cm}$ with 11 to 41 lanceolate leaflets. These leaflets are 7-13 $\mathrm{cm}$ and have a smooth margin except for a basal tooth with a gland on the abaxial surface. The twigs are stout with 0.5 to $1.0 \mathrm{~cm}$ shield shaped leaf scars and prominent lenticels. The inflorescence is a 20-40 cm terminal panicle. The yellowish green, usually unisexual or perfect flowers have 5 petals. The plants are polygamo-dioecious. The fruit is a $3-5 \mathrm{~cm}$ long and 0.8-1.4 wide samara with pointed, twisted wings at each end of the seed cavity. 
Ailanthus altissima is genetically variable in the United States and is also genetically different from Chinese Ailanthus. A study by Feret and Bryant (1974) showed that the seeds from the two countries yielded seedlings with that differed for seven of nine measured characteristics and for four of five measurements of biomass distribution.

\section{Range}

Originating in Southeast Asia, tree-of-heaven is now found on all continents except Antarctica (Udvardy, 1998). In the Mediterranean region, it has spread abundantly through a broad range of sites. In central Europe, however, it is effectively confined to warmer regions or to urban areas where there is a more favorable microclimate (Sukopp and Wurzel, 2000). In the Americas, tree-of-heaven "runs wild from Massachusetts...to Oregon... and from Toronto...to Argentina (Hu, 1979)." In the United States, it is ubiquitous in the Northeast, becomes sparse in the deep south, is rare on the Atlantic coastal plain, is frequently found in the upper mid-west, and occasionally locally appears in the Rocky Mountains and California (Elias, 1980). Of the five species of Ailanthus in the Simaroubaceae, A. altissima is the only one that has adapted well to the temperature environment of North America (Shah, 1997).

\section{Site}

Tree-of-heaven is quite plastic in terms of the sites on which it can grow. It has been touted as a suitable species for afforestation in the hot deserts of Pakistan because it survives in low moisture environments (Ashraf and Sham-ur-Rehman, 2001). It has also been observed growing in a freshwater tidal estuary in Maryland (Kiviat, 2004), in a rain gutter in Milwaukee, Wisconsin, and in Rhode Island where a stand was found with roots submerged in sea water 
(Newton, 1986). Tree-of-heaven frequently forms dense clumps around stockyards and old homestead sites throughout southern Australia (Cunningham et al., 1981). It has a great altitudinal range, growing from sea level to at least 5200 feet in the Denver, CO area. It can be found on rich bottomlands, limestone outcrops, and lines many highways in the Mid-Atlantic States (Feret, 1985). It can be found in urban areas, not only as a planted street tree, but also inhabiting vacant lots, sidewalk cracks, culverts, and subway gratings. Newton (1986) may have summed it up best saying, "Give an Ailanthus a teaspoon of organic matter and a few drops of water and it's on its way."

Tree-of-heaven is generally thought to be shade intolerant, although some have touted it as a shade tolerant species (Grime 1965) and attribute this to its apparent competitive edge. A study by Bourdeau and Laverick (1958) shows that not only is A. altissima shade intolerant, but its leaves showed a negative adaptation to light intensity with shade leaves less efficient than sun leaves.

Tree-of-heaven is said to be sensitive to frost during its early years (Adamik and Brauns, 1957), but six-year-old stems have been noted as surviving winters of $-33^{\circ} \mathrm{C}$ with high winds (Hoshovsky, 1988).

Some contend that $A$. altissima is not drought-hardy since it is not often found in association with pines and junipers (Feret, 1985), but it has been noted as growing on dry sites in North America (Illick and Brouse, 1986), China (Richardson, 1966), and the desserts of Pakistan (Ashraf and Sham-ur-Rehman, 2001). Ailanthus and juniper were also found to be the two most drought resistant species in the Kansas in the drought of 1934 (Stiles and Melchers, 1935). Richarson (1966) noted its growth in "special problem sites," such as sand dunes, in many regions of China including Inner Mongolia, Sinkiang, Kansu, and Tsinghai. Drought-hardiness 
may be attributed to the ability of tree-of-heaven to store water in swollen roots near the base of the stem (Bryant, 1973). Feret (1985) also suggest that shedding of transpiring plant parts during dry periods, and the ability to resprout, may contribute to drought-hardiness. A study by Trifilò et al. (2004) concluded that $A$. altissima seedlings are able to withstand drought by employing a highly effective water-saving mechanism that involves reduced water loss by leaves and reduced root hydraulic conductance.

Soil tolerances of the species are not well understood or well documented. It has been sited as "growing well on very saline shell sands," (Lavrimenko and Volkov 1973) while Adamik and Brauns (1957) said, "salty soils are not suitable for growth". It tolerated a pH of less than 4.1, soluble salt concentrations up to $0.25 \mathrm{mmhos} / \mathrm{cm}$, and phosphorous levels as low as $1.8 \mathrm{ppm}$ when used to revegetate mine spoils (Plass 1975).

Tree-of-heaven is consitently described as a shade intolerant species. It has been documented growing as part of the subcanopy and shrublayers of a closed canopy forest system near Seneca Rocks, WV (Kowarick, 1995) and in several small treefall gaps in an old growth forest in Montgomery Place South Woods in Dutchess County, New York (Knapp and Canham, 2000). In both of these examples, A. altissima was found growing in canopy gaps and there was no second year survival of seedlings under the canopy. Kiviat (1978) noted a high level of deer herbivory in Montgomery Place and predicted that unpalatable species may eventually become dominant there. Ailanthus altissima, an unpalatable species (Forgione, 1993) is becoming dominant here and could have a significant advantage in areas with high deer populations (Knapp and Canham, 2000). 


\section{Pathogens}

Tree-of-heaven has been reported to be resistant to insect predation, root-feeding nematodes, and fungi (Adamik and Brauns, 1957; Goor and Barney, 1968; Hepting, 1971; Feret, 1985; Milller, 1990; Santamour and Riedel, 1993).

The development of most insect larvae is inhibited by quassinoid containing compounds in tree-of-heaven, which also retards rotting (Heisey, 1996). Several instances of indigenous insect species spending all or part of their life cycles on A. altissima are cited in the Japanese literature (Feret, 1985). Two lepidopteron (Atteva punctella and Samia synthia) and the Asiatic garden beetle (Maladera castenea) feed on tree-of-heaven foliage, but also damage desirable plant species (Mohonadas and Verma, 1984; Miller, 1990).

Although tree-of-heaven is resistant to fungi, it is not immune; six species of fungi attack the foliage, ten attack the stem and vascular system, and five species of decay fungi have been isolated from the roots and rotting trunks (Hepting, 1971). Perhaps the most promising fungal pathogens to tree-of-heaven are Veticillium dahliae and Fusarium oxysporum (Hepting, 1971; Miller, 1990), but only if strains affecting only A. altissima can be found.

\section{Reproduction and propagation}

Ailanthus altissima spreads rhizomatously, forming extensive clones (Kowarick, 1995). Clonal growth is not necessarily the preferred method of reproduction, but often a response to injury to the parent plant. Ramets are also often observed during the founder phase of invasion; Pan and Bassuk (1986) found seedlings and clonal ramets established in equal numbers on an open urban site. The fact that $A$. altissima, as a shade intolerant species, establishes a ramet bank under shady conditions may indicate an alternative pathway to enhance the persistence of the genet (Kowarick, 1995). Seed banking is not thought to be a reproductive strategy of this species 
as the longevity of its seeds in soil does not exceed one year (Krüssmann et al., 1981).

Precocious flowering is not rare in this species and has been observed in seedlings as young as 6 weeks (Feret, 1973).

The population dynamics of rodents may have an effect on the success of invasion of Ailanthus altissima. Ostfeld et al. (1997) found that voles prefer Ailanthus altissima seeds over those of many native species, but it is not a preferred species for seed predation by mice. Mice will however consume tree-of-heaven seeds when mouse densities are high. In years when mice populations dominate over those of voles, Ailanthus invasion is favored through preferential seed predation. The composition of small-mammal communities in old fields appears to affect the rate of tree invasion, species of invasion, and the spatial pattern of invading trees.

Ashraf and Sham-ur-Rehman (2001) showed rooting percentages of 15 and 70 percent of roots and branches respectively in Pakistan where A. altissima is an important species for afforestation.

\section{Palatability}

Mortalities of livestock have been anecdotally associated with ingestion of tree-of-heaven in Australia since at least 1911 (Hurst, 1942). A study by Bourke (1996) suggests that goats should be able to ingest significant amounts of $A$. altissima foliage and stem material for long periods of time without ill effect. In this study two goats were fed exclusively A. altissima foliage, and two others bark extracts for periods of 104 and 56 days respectively. All goats maintained their body weight over the study period and remained in good health during the trial and for the following six months. 


\section{Allelopathy}

Allelopathy is simply defined as the production of chemicals by one species that affect another species (Newman, 1983), usually in a detrimental manner (Rice 1984). These intereactions may be insecticidal (Osbourne et al., 1988), herbicidal (Muller and Muller, 1964), and antipredator (Robbins et al., 1987). Allelopathy in tree-of-heaven was first noted by Mergen (1959) who tested it under greenhouse conditions. Active compounds have been isolated from tree-of-heaven including ailanthone, ailanthinone, chaparrine, and ailanthinol B (DeFeo et al., 2003). The compound with greatest herbicidal activity is ailanthone. This suggests a possible use of tree-of-heaven root extracts or of its active constituents as natural herbicides.

Production of a plant extract that is toxic to surrounding species is not difficult (Gliessman 1983; Mandava 1985), and is not sufficient to indicate an allelopathic relationship. An average of one in 40 plant species was shown to produce a water extract that reduced radicle elongation in at least one of three species in the state of Washington (del Moral and Cates 1971). These results indicate, at best, a potential for allelopathic interactions. Field studies of allelopathic relationships between tree-of-heaven and neighboring species may be the only way to assess the ecological impacts that allelopathy may have in A. altissima infested areas.

A field study by Lawrence et al. (1991) showed that compounds found in tree-of-heaven can inhibit the germination and growth of associated plant species. These compounds are present in the soil in detectable concentrations and are transmitted to individuals of neighboring plant species. This study also showed that progeny of plants growing adjacent to Ailanthus altissima are, in general, better suited to growing in Ailanthus infested environments, indicating that allelopathic chemical produced by Ailanthus has tangible effects on neighboring species. 
This influence may not only control the spatial distribution of plants in a community, but may also provide stress that contributes to environmental change within associated plant populations.

While it has been shown that allelopathic chemicals may act to inhibit the germination of associated species and inhibit their growth, it is not clear whether this is the primary purpose of the chemicals. It is possible that the herbicidal effects are only secondary mechanisms of the chemicals produced, and that their primary purpose is insecticidal or anti-predator.

\section{As an Invader}

That so many species invade repeatedly, lends credence to the idea that whereas interactions with the environment may affect invasiveness, the characteristics of the species themselves dominate invasive ability (Reichard and Hamilton, 1997). The life history of successful invaders is an important characteristic to use in predicting invasiveness of a species (Parker et al., 1999; Reichard and Hamilton 1997). Many invasive species have characteristics that allow them to become better competitors than their native counterparts, allowing them to spread and impact the environment in which they have become established, altering fundamental ecological properties such as the dominant species, nutrient cycling, and plant productivity.

Ailanthus altissima exhibits many of the characteristics shared by many successful exotic colonizers including rapid growth rate (Illick and Brouse, 1926; Petrides, 1978; Bazaaz, 1979; Feret, 1985; Heisey, 1990), large numbers of small wind borne seeds and vegetative reproduction (Hu, 1979), tolerates stress (Graves et al., 1989), and eurytopy, the ability of an organism to tolerate a wide range of environmental factors (ecological generalism) (Newton, 1986; Kiviat, 2004). Disturbance may be important in invasion success because it creates growing space, alters soil structure and nutrients, or alters other site factors such as light availability. 
Even though it is listed as an important exotic weed by the Nature Conservancy (Hoshkovy, 1999), it is not often identified as a serious threat to native flora (e.g. Cronk and Fuller, 1995)

\section{Uses of A. altissima}

Although primarily used in the United States as an ornamental, tree-of-heaven has been used in many countries for a variety of purposes including shelterbelts, afforestation, reforestation, silkworms, fuelwood, and fodder for goats and cattle (Feret, 1985). It has been recommended for plantings in difficult sites in urban areas by many authors (Tice, 1888; Parsons, 1915; Edin, 1978; Elias, 1980). Tree-of-heaven has been used for reforestation of slopes, dunes, barren areas and for windbreaks in Austria, Italy, the former Yugoslavia, in dunes of the Black Sea, in dry areas of southeastern Europe and Asia Minor, and in the Soviet Union (Udvardy, 1998).

The wood of tree-of-heaven may be useful in some commercial applications. The wood properties resemble those of ash (Moslemi and Bhagwat, 1970). The pulpwood characteristics of tree-of-heaven are acceptable and in some ways are superior to aspen (Vidal and Aribert, 1927; Adamik and Braun, 1957; Narayanamurti and Singh, 1962). Illick and Brouse (1926) showed that tree-of-heaven has potential as a producer of wood. It rarely reaches heights greater than 60-70 feet but has rapid juvenile growth. The stand analyzed by Illick and Brouse produced 50 cords of wood in only 30 years for a mean annual yield increment of 1.7 cords/ac/yr. While this does not compare favorably with species such as loblolly pine (Pinus taeda L.) (capable of producing over 2.0 cords/ac/yr), its yield is respectable for a hardwood species. It has been planted for industrial use in Argentina, Uruguay, India, New Zealand, Austria, and in East Europe (Udvardy, 1998). 
In the early $19^{\text {th }}$ century, nurseries were commissioned to plant $A$. altissima to evaluate the tree's usefulness in timber for uses in furniture, railroad ties, and fuel (Douglas, 1882; Meehan, 1885; Sargent, 1888). These efforts failed and by the 1920's $A$. altissima was no longer used in the United States.

Tree-of-heaven has been planted in France and northern Italy as a host plant for the treeof-heaven silkworm (Bombyx cynthia). In Turin, France in 1862, Father Fantoni found that, when reared on Ailanthus, the silkworm (Bombyx cynthia) produced superior silk to that reaped from mulberry fed worms, giving the species a boost in Europe (Guerrin-Manville, 1862). Since Father Fantoni's findings, the quality of silk produced from Ailanthus altissima has been questioned, and it has been said that despite its low cost, the silk can not rival the silk of true silkworms raised on mulberry trees (Morus alba L.) (Udvardy, 1998).

Perhaps the most promising possible use of Ailanthus altissima is as a source of natural herbicides. Ailanthone, an allelopathic compound of tree-of-heaven, is a very powerful herbicidal compound. A study by Heisey (1996) showed that radical growth of garden cress was reduced to 50 percent by a solution containing only $0.7 \mathrm{ppm}$ of ailanthone. A natural herbicide could have many advantages over a synthetic one including: 1) rapid degradation in the natural environment, resulting in less environmental pollution, 2) reduced dependence on fossil fuels , and 3) lower toxicity of the herbicide on non-target organisms (Heisey 1997). More research needs to be conducted to determine other possible herbicidal chemicals from tree-of-heaven and to reduce the cost of extraction of these chemicals before its use as a natural herbicide can be fully realized. 


\section{Problems associated with A. altissima}

A growing body of work shows that non-indigenous invasive species such as Ailanthus altissima decrease native biodiversity and alter ecosystem functioning (Vitousek and Walker 1989; D’Antonio and Vitousek, 1992; Schmitz et al., 1997; Walker and Steffen, 1997; Parker and Reichard, 1998).

Ailanthus altissima has been observed growing in forest gaps (Kowarik, 1995; Knapp and Canham, 2000). Gaps are common in many old growth and second growth forests, and many species depend on natural openings (gap-phase dynamics) to regenerate. Natural or managed regeneration of forests through gap-phase dynamics could promote invasion by exotic species (Huebner, 2003), especially those species which cannot successfully invade closed canopy systems. This species has also been noted growing on logging roads, along skid trails, and invading silvicutural cuts such as shelterwoods (Call and Nilsen 2003).

Invasive species such as $A$. altissima may alter fire regimes by decreasing the flammability of grass fuels or by increasing the potential for high intensity fires when control efforts increase loadings of dead, downed woody material (Richburg et al., 2001).

Exotic plant invasion may also be increased when forests are disturbed via exotic insect infestation (Liebhold et al., 1995). Orwig and Foster (1998) found that many non-native invasives, including Ailanthus altissima, were invading stands defoliated by the hemlock woolly adelgid in southern New England. Tree-of-heaven could have a significant advantage in areas with high deer populations (Knapp and Canham, 2000) since it is considered an unpalatable species (Forgione, 1993).

Feret (1985) cites many problems with use of this tree as an ornamental. Once established as an ornamental, the tree is hard to remove because of the persistent stump and root 
sprouts. The tree sheds large numbers of rachii which are difficult to clean from streets and gutters. The allelopathic properties of the species may also make mixed species plantings including tree-of-heaven undesirable. Also, the root system is aggressive enough to cause damage to sewers and foundations ( $\mathrm{Hu} 1979)$.

Contact with the leaves of tree-of-heaven may cause dermatitis and/or stomach pains (Pammel, 1911; Muenscher, 1944; Derrick and Darley, 1994). Derrick and Darley (1994) reported that a 19-year old agricultural student who was hand pulling tree-of-heaven stems developed a rash (urticated eczematous eruption, with no bullae). The condition was easily treated with topical corticosteroids and oral antihistamines, but the absence of any reports of similar skin problems in other horticultural workers, and the fact that tree-of-heaven is not rare, together suggest allergy.

The pollen of this tree is also a known allergen (Blumstein, 1943; Ballero et al., 2003). A study by Ballero et al. (2003) showed that Ailanthus pollen should be considered a serious allergen in areas where it is common. In their study ten of fifty-four randomly selected patients showed positive allergic reactions to $A$. altissima extracts.

\section{Controls}

A successful control method kills the stems and roots while allowing for the reestablishment of native vegetation on the site (Burch and Zedaker, 2003). Possible control methods include manual (hand pulling, digging, girdling), mechanical (chopping, cutting or mowing), burning, grazing, biocontrol, and chemical (Hoshovsky, 1988).

Manual controls such as hand pulling and digging may be effective when the stems are quite small, but becomes difficult with a developed root system. Hand pulling may be effective in seedlings but not for root sprouts as all of the root material must be removed to prevent further 
sprouting. In dense or large stands of tree-of-heaven, pulling and digging become impractical. Repeated and persistent cutting of tree-of-heaven stems can usually kill the tree (Randall and Martinelli, 1996), but this often requires multiple visits to the tree each growing season for several years. Generally cutting, chopping, and girdling of A. altissima stimulate resprouting and increased overall stand density so these mechanical and manual treatments should be avoided to prevent proliferation (Burch and Zedaker, 2003).

Controlled burns or spot treating (heat girdling) with fire may be used to control tree-ofheaven. The advantages of these treatments are that they can be conducted at any time of the year and are less costly than most chemical treatments (Hoshovsky 1988). A problem is that once again, the roots are not destroyed and will resprout after burning.

Recent studies have shown that some livestock may be able to ingest large amounts of Ailanthus altissima stems (e.g. Bourke, 1996). While this removal of stems may weaken the roots, as burning may, neither method causes mortality of the extensive root system and may promote sprouting (Burch and Zedaker, 2003). Tree-of-heaven may suffer extensive browse herbivory from deer and cattle, particularly the young growth of sprouts, which may aid eradication (Pannill 1995), but grazing is not an option in many of the area where ailanthus has previously invaded, such as road cuts and highway medians.

Two lepidopteron (Atteva punctella and Samia synthia) and the Asiatic garden beetle (Maladera castenea) feed on tree-of-heaven foliage, but also damage desirable plant species (Mohonadas and Verma, 1984; Miller, 1990). There are few known disease and insect pests of Ailanthus altissima so at the present time; biological control is not an option.

Although tree-of-heaven is resistant to fungi, it is not immune; six species of fungi attack the foliage, ten attack the stem and vascular system, and five species of decay fungi have been 
isolated from the roots and rotting trunks (Hepting, 1971). Heptig (1971) and Miller (1990) suggests that perhaps Verticillium spp and Fusarium oxysporum are potentially the most important fungal disease of the species, but are not effective enough to seriously consider singularly as a control measures and could be considered only if strains affecting just $A$. altissima can be found.

Chemical treatments are often performed on Ailanthus altissima with differing levels of success. The only successful treatment is one that not only top kills the tree, but also controls sprouting and suckering by translocating into roots. Foliar broadcast applications are effective in defoliating this species. Basal bark application may be used on small trees, and cutting larger stems and immediately brushing fresh-cut stem surfaces with glyphosate herbicide may be effective (Randall and Martinelli, 1996). Burch and Zedaker (2003) were successful in not only removing existing trees, but also prevented resprouting and allowed for reestablishment of native vegetation in a study in Virginia. In this study, basal bark treatments with an herbicide combination including picloram (at least 5\% Tordon K) proved most successful. Garlon 4, Stalker, and a combination of Garlon 4 and Stalker all controlled A. altissima better than cutting, but were not as effective as treatments containing picloram.

The quandary is that the label for Tordon $\mathrm{K}$ (picloram) says, "Picloram is a chemical which can travel (seep or leach) through soil and under certain conditions has the potential to contaminate groundwater which may be used for irrigation and drinking purposes." Because of this, it may be advisable to formulate a prescription that does not include the use of picloram. 


\section{References}

Adamik, K. and F.E. Braun. 1957. A. altissima as pulpwood. Technical Association of the Pulp and Paper Industry (TAPPI). 40:522-526.

Allan, D.G., J.A. Harrison, R.A. Navarro, B.W. van Wilgen, and M.W. Thompson. 1997. The impact of commercial afforestation on bird populations in Mpumalanga province, South Africa: insights form bird-atlas data. Biological Conservation. 79:173-185.

Anable, M.E., M.P. McClaren, G.B. Ruyle. 1992. Spread of introduced Lehmann lovegrass Eragrostis tehmanniana Nees. in southern Arizona. Biological Conservation. 61:181-188.

Ballero, M., A.Ariu, P.Falagiani, and G.Piu. 2003. Allergy to Ailanthus altissima (tree of heaven) pollen. Allergy. 58(6):532-533.

Bazaaz, F.A. 1979. The physiological ecology of plant succession. Annual Review of Ecological Systems. 10:351-371.

Blumstein, G.I. 1943. Sensitivity to ailanthus pollen with report of two clinically sensitive patients. Journal of Allergy and Clinical Immunology. 14:329-334.

Bourdeau, P.F. and M.L. Laverick. 1958. Tolerance and photosynthetic adaptability to light intensity in white pine, red pine, hemlock and Ailanthus seedlings. Forest Science. 4(3):196207.

Bouke, C.A. 1996. Lack of toxicity of Ailanthus altissima (tree of heaven) for goats. Australian Veterinary Journal. 74(6):465.

Brown, R.W. 1941. Some prehistoric trees of the United States. Journal of Forestry. 41:861-868.

Bryant, R.L. 1973 Genetic variation in ailanthus. MS thesis. Department of Forestry. Virginia Polytechnic Institute and State University. Blacksburg, VA 24060. 60pp.

Burch, P.L. and S.M. Zedaker. 2003. Removing the invasive tree Ailanthus altissima and restoring natural cover. Journal of Arboriculture. 29(1):18-24.

Call, L.J., and E.T. Nilson. 2003. Analysis of Spatial Patterns and Spatial Association between the Invasive Tree-of-Heaven (Ailanthus altissima) and the Native Black Locust (Robinia pseudoacacia). American Midland Naturalist. 150:1-14

Callaway, R.M. and E.T. Aschehoug. 2000. Invasive plants versus their new and old neighbors: a mechanism for exotic invasion. Science. 290:521-523.

Cronk, Q.B. and J.L. Fuller. 1995. Plant Invaders: the Threat to Natural Ecosystems. Chapman and Hall. London, UK.

Cunningham, G.M., W.E. Mulham, P.L. Milthorpe, and J.H. Leigh. 1981. Plants of Western New South Wales. NSW Government Printing Office. Sydney. p.450.

D'Antonio, C.M. and P.M. Vitousek. 1992. Biological invasions by exotic grasses, the grass/fire cycle, and global change. Annual Review of Ecological Systems. 23:63-87.

Davies, P.A. 1942. The history, distribution, and value of ailanthus. Transactions of the Kentucky Academy of Science. 9(1):12-14

de la Cretaz, A. and M. Kelty. 1999. Establishment and control of hay-scented fern: a native invasive species. Biological Invasions. 1:223-236. 
del Moral, R. and R.G. Cates. 1971. Allelopathic potential of the dominant vegetation of western Washington. Ecology. 52:1030-1037.

Derrick, E.K. and C.R. Darley. 1994. Contact reaction to the tree of heaven. Contact Dermatitis. 30:178.

Dillwyn, L.W, ed. 1843. Hortus Collinsoniansus Swansea: privately published. p.2.

Douglas, H. 1882. Gardeners Monthly. 24(280):117.

Downing, A.J. 1841. Treatise on the Theory and Practice of Landscape Gardening, $1^{\text {st }}$ ed. New York, NY. pp. 202-204.

Downing, A.J. 1847. The Horticulturalist. I(9):397.

Downing, A.J. 1852. Shade trees in cities. The Horticulturalist. 7(8):345-349.

Edin, H.L. 1978. The Illustrated Encyclopedia of Trees, Timbers, and Forests of the World. Salamander Books. London. 266pp.

Elias, T.S. 1980. The Complete Trees of North America. Van Nostrand Reinhold. New York, NY. 948pp.

Executive Order 13112. 1999. "Invasive Species" William J. Clinton. Federal Register. 64(25):6183-6186.

Feret, P.P. 1985. Ailanthus: Variation, Cultivation, and Frustration. Journal of Arboriculture. 11(12):361-368.

Feret, P.P. and R.L. Bryant. 1974. Genetic differences between American and Chinese Ailanthus seedlings. Silvae Genetica. 23(5):144-148.

Forgione, H.M. 1993. Limits to the establishment and growth of tree-of-heaven explored (New Jersey). Restoration Management Notes. 11:70-71.

Fralish, J.S. and S.B. Franklin. 2000. Taxonomy and Ecology of Woody Plants in North American Forests (excluding Mexico and Subtropical Florida). John Wiley and Sons. New York, NY.p.409.

Gliessman, S.R. 1983. Allelopathic interactions in crop-weed mixtures: application for weed management. Journal of Chemical Ecology. 9:991-999.

Goor, A.Y. and C.W. Barney. 1968. Forest Tree Planting in Arid Zones. Ronald Press. New York, NY. 409pp.

Graves, W.R., N.M. Dana, and R.J. Joly. 1989. Influence of root-zone temperature on growth of Ailanthus altissima (Mill.) Swingle. Journal of Environmental Horticulture. 7:79-82.

Grime, J.P. 1965. Shade tolerance in flowering plants. Nature. 208:161-163.

Guerrin-Manville, M.F.-E. 1862. The ailanthus silkworm and the ailanthus tree. Technologist. 2:336-343.

Heisey, R.M. 1990. Allelopathic and herbicidal effects of extracts from tree of heaven (Ailanthus altissima). American Journal of Botany. 77:662-670.

Heisey, R.M. 1996. Identification of an allelopathic compound from Ailanthus altissima (Simbrouaceae) and characterization of its herbicidal activity. American Journal of Botany. 83(2):192-200. 
Heptig, G.H. 1971. Diseases of forest and shade trees of the United States. Department of Agriculture. Handbook 386. Washington, DC. 658pp.

Higgins, S.I., D.M. Richardson, and R.M. Cowling. 1996. Modeling invasive plant spread: the role of plant-environment interactions and model structure. Ecology. 77:2043-2054.

Higgins, S.I., D.M. Richardson, R. M. Cowling, and D. H. Trinder-Smith. 1999. Predicting the Landscape-Scale Distribution of Alien Plants and Their Threat to Plant Diversity. Conservation Biology. 13(2):303-313.

Hoshovsky, M.C. 1988. Element Stewardship Abstract: Ailanthus altissima (tree of heaven). The Nature Conservency. Arlington, VA. Available online: http://tncweeds.ucdavis.edu/esadocs/documnts/ailaalt.html

Hu, S.Y. 1979. Ailanthus. Arnoldia. 39(2):29-50.

Huebner, C.D. 2003. Vulnerability of oak-dominated forests in West Virginia to invasive exotic plants: temporal and spatial patterns of nine exotic species using herbarium records and land classification data. Castanea. 68(1):1-14.

Huenneke, L.F., S.P. Hamburg, R. Kloide, H.A. Mooney, and P.M. Vitousek. 1990. Effects of Soil Resources on Plant Invasion and Community Structure in Californian Serpentine Grassland. Ecology. 71(2):478-491.

Hurst, E. 1942. The Poisonous Plants of New South Wales. Poison Plants Committee of New South Wales, Sydney. p.213.

Illick, J.S., and E.F. Brouse. 1926. The ailanthus tree in Pennsylvania. Pennsylvania Department of Forestry and Waters. Bulletin 38. 29pp.

Kiviat, E. 2004. Occurrence of Ailanthus altissima in a Maryland Freshwater Tidal Estuary. Castanea. 69(2):139-142.

Knapp, L.B. and C.D. Canham. 2000. Invasion of an old-growth forest in New York by Ailanthus altissima: sapling growth and recruitment in canopy gaps. Journal of the Torrey Botanical Society. 127(4):307-315.

Kowarik, I. 1995. Clonal growth in Ailanthus altissima on a natural site in West Virginia. Journal of Vegetation Science. 6:853-856.

Krüssmann, G., G. Wennemuth, and H.E. Thon. 1981. Die Baumschule. $5^{\text {th }}$ ed. Parey. Berling, Hamburg.

Lavrinenko, D. D. and F. I. Volkov. 1973. Salt resistance of species on the coast of the Sea of Azov. Lesnoe Khozyaistro 9:33-36. Sited in: Hoshovsky, 1999.

Lawrence, J.G., A. Colwell, and O.J. Sexton. 1991. The ecological impact of allelopathy in Ailanthus altissima (Simbrouaceae). American Journal of Botany. 78:948-958.

Le Maitre, D.C., B.W. van Wilgen, R.A. Chapman, and D.H. McKelly. 1996. Invasive species and water resources in the western cape province, South Africa: modeling the consequences of a lack of management. Journal of Applied Ecology. 33:161-172.

Levine, J.M. and C.M. D’Antonio. 1999. Elton revisited: a review of evidence linking diversity and invasibility. Oikos. 87:15-26. 
Liebhold, A.M., W.L. MacDonald, D. Bergdahl, and V.C. Mastro. 1995. Invasion by exotic forest pests: a threat to forest ecosystems. Forest Science Monographs. 30:1-49.

Little, E.L. 1979. Checklist of United State Trees (Native and Naturalized). U.S. Department of Agriculture. Agricultural Handbook No. 541. p.47.

Mandava, N. 1985. The chemistry and biology of allelopathic agents. In: A.D. Thompson, ed. The chemistry of allelopathy. American Chemical Society Monograph Series. 268. American Chemical Society. Washington, D.C. pp.33-54.

Meehan, T. 1885. Gardeners Monthly. 28(324):369-370.

Mergen, F. 1959. A toxic principle in the leaves of Ailanthus. Botanical Gazette. 120:32-36.

Meyer, J.Y. and J. Florence. 1996. Tahiti's native flora endangered by the invasion of Miconia calvascens DC. Journal of Biogeography. 23:775-782.

Miller, J.H. 1990. Ailanthus altissima (Mill.) Swingle. In: Burns, R.M and Honkala, B.H., technical coordinators. Silvics of North America: Volume 2 Hardwoods. Department of Agriculture. Handbook 654. pp.101-104.

Mohonadas, K. and R.V. Verma. 1984. A new host record for Atteva fabriciella (Lepidoptera:Yponomeutidae) a pest of Ailanthus. Journal of Tree Science. 3(1/2):128.

Moslemi, A.A., and S.G. Bhagwat. 1970. Physical and mechanical properties of the wood of tree of heaven. Wood and Fiber. 1:319-323.

Muenscher, W.C. 1944. Poisonous Plants of the United States. Macmillan. New York, NY.

Muller, W.H. and C.H. Muller. 1964. Volatile growth inhibitors produced by Salvia species. Bulletin of the Torrey Botanical Club. 91:327-330.

Musil, C.F. 1993. Effects of invasive Australian acacias on the regeneration, growth and nutrient chemistry of South African lowland fynbos. Journal of Applied Ecology. 30:361-372.

Narayanamurti, D. and K. Singh. 1962. Boards from A. altissima. Indian Pulp and Paper. 17(2):167-168.

Newman, E.I. 1983. Interactions between plants. In: Lang, O.L., P.S. Nobel, C.B. Osmond, and H. Ziegler, eds. Physiological Plant Ecology III: responses to the chemical and biological environment. Springer-Verlag. Berlin.

Newton, E. 1986. Arboreal riffraff or ultimate tree? Audubon. 88:12-19.

Osbourne, T.C., D.C. Alexander, S.S.M. Sun, C. Cardona, and S.A. Bliss. 1988. Insecticidal action and lectin homology of arcelin seed proteins. Science. 240:207-210.

Ostfeld, R.S., R.H. Manson, and C.D. Canham. 1997. Effects of rodents on survival of tree seeds and seedlings invading old fields. Ecology. 78(5):1531-1542.

Pammel, D. 1911. A Manual of Poisonous Plants. Torch Press. Cedar Rapids, IA.

Pan, E. and N. Bassuk. 1986. Establishment and distribution of Ailanthus altissima in the urban environment. Journal of Environmental Horticulture. 4:1-4.

Pannill, P. 1995. Tree-of-Heaven control. Maryland Department of Natural Resources Forest Service Stewardship Bulletin. 8 pp. 
Parker, I. M. and S. H. Reichard. 1998. Critical issues in invasion biology for conservation science. In: Fiedler, P.L. and P.M. Kareiva, eds. Conservation biology: for the coming decade. 2nd ed. Chapman and Hall. New York, NY. pp.283 305.

Parsons, S. Jr. 1915. The Art of Landscape Architecture. Putnam. New York, NY. p.315.

Petrides, G.A. 1986. A Field Guide to Trees and Shrubs. Houghton Mifflin. Boston, MA.

Plass, W.T. 1975. An evaluation of trees and shrubs for planting surface mine spoils. USDA Forest Service. North East Forest Experimental Station Research Paper NE 317. 8pp.

Randal, J.M. and J. Martinelli. 1996. Invasive Plants: Weeds of the Global Garden. Brooklyn Botanical Gardens. Brooklyn, NY. p.27.

Rejmanek, M. and J. Randall. 1994. Invasive alien plants in California: 1993 summary and comparison with other areas in North America. Madrono. 41:161-177.

Rheder, A. 1954. Manual of Cultivated Trees and Shrubs. Macmillan. New York, NY. pp.531532.

Rice, E.L. 1984. Allelopathy. Academic Press. New York, NY.

Richardson, S.D. 1966. Forestry in Communist China. John Hopkins Press. Baltimore, MD. pp.78-80, 114.

Richburg, J.A., A.C. Dibble, and W.A. Patterson, III. 2001. Woody invasive species and their role in altering fire regimes of the northeast and mid-Atlantic states. pp.104-111. In: Galley, K.E.M. and T.P. Wilson, eds. Proceedings of the Invasive Species Workshop: the Role of Fire in the Control and Spread of Invasive Species. Fire Conference 2000. Miscellaneous Publication No. 11, Tall Timbers Research Station. Tallahassee, FL.

Robbins, C.T., T.A. Hanley, A.E. Hagerman, O. Hjeijord, D.L. Baker, C.C. Schwartz, and W. Mautz. 1987. Role of tannins in defending plants against ruminants: reduction in protein availability. Ecology. 68:98-107.

Santamour, F.S. and L.G.H. Riedel. 1993. Susceptibility of various landscape trees to root-knot nematodes. Journal of Arboriculture. 19(5):257-259.

Sargent, C.S. 1888. Garden and Forest. I:385-386.

Schmitz, D.C., D.Simberloff, R.H. Hofstetter, W. Haller and D. Sutton. 1997. The ecological impact of nonindigenous plants. In: Simberloff, D., D.C. Schmitz, and T.C. Brown, eds. Strangers in Paradise: Impact and Management of Nonindigenous Species in Florida,. Island Press. Washington, DC. Pp.39-61

Shah, B. 1997. The checkered career of Ailanthus altissima. Arnoldia. 57(3):20-27.

Siren, O. 1949. Gardens of China. Ronald House. New York, NY. p.38.

Smith, B.A. 1943. A Tree Grows in Brooklyn. Harper Collins. New York, NY.

Stenkamp, H.E., and S.L. Chown. 1996. Influence of dense stands of an exotic tree, Prosopis glandulosa Benson, on a savanna dung beetle assemblage in southern Africa. Biological Conservation. 78:305-311.

Stiles, E.H., and L.E. Melchers. 1935. The drought of 1934 and its effect on trees in Kansas. Transactions of the Kansas Academy of Science. 38:107-127. 
Sukopp, H. and A. Wurzel. 2000. Changing climate and the effects on vegetation in central European cities. Arboricultural Journal. 24:257-281.

Swingle, W.T. 1916. The early European history and the botanical name of the tree of heaven, Ailanthus altissima. Journal of the Washington Academy of Sciences. 6:490-498.

Tice, C.V ed. 1888. Correspondence, C.S. Sargent. Garden and Forest. I:179-180.

Trifilò, P., F. Raimondo, A. Nardini, M.A. LoGullo, and S. Salleo. 2004. Drought resistance of Ailanthus altissima: root hydraulics and water relations. Tree Physiology. 24(1):107-114.

Udvardy, L. 1998. Classification of adventives dangerous to the Hungarian natural flora. Acta Botanica Hungarica. 41:315-331.

U.S. Congress, Office of Technology Assessment. 1993. Harmful nonindigenous species in the United States. OTA-F-565. U.S. Government Printing Office, Washington, D.C.

Uva, R.H., J.C. Neal, \& J.M. DiTomaso. 1997. Weeds of the Northeast. Cornell University Press. Ithaca, New York. 397pp. Cited in: USDA, NRCS. 2004. The PLANTS Database, Version 3.5 (http://plants.usda.gov). National Plant Data Center, Baton Rouge, LA 70874-4490 USA.

Vidal, L. and M. Aribert. 1927. Ailanthus wood as a paper-making material. Paper Trade Journal. 85:49-50.

Vitousek, P.M. and L.R. Walker. 1989. Biological invasion by Myrica faya in Hawaii: plant demography, nitrogen fixation, ecosystem effects. Ecological Monographs. 59:247-265.

Vitousek, P. M., H. A. Mooney, J. Lubchenco, and J. M. Melillo. 1997. Human domination of Earth's ecosystems. Science 277:494-499.

Vitousek, P.M. and L.R. Walker. 1989. Biological invasions by Myricacia faya in Hawaii: plant demography, nitrogen fixation, ecosystem effects. Ecological Monographs. 59:247-265.

Walker, B. and W. Steffen. 1997. An overview of the implications of global change for natural and managed terrestrial ecosystems. Conservation Ecology. 1(2):2.

Whitson, T.D. (ed.) 1996. Weeds of the West. Western Society of Weed Science in cooperation with Cooperative Extension Services, University of Wyoming. Laramie, Wyoming. 630pp. Cited in: USDA, NRCS. 2004. The PLANTS Database, Version 3.5 (http://plants.usda.gov). National Plant Data Center, Baton Rouge, LA 70874-4490 USA. 


\title{
Chapter 1. Testing the Efficacy of Triclopyr and Imazapyr Using Two Application Methods for Controlling Tree-of-heaven along a West Virginia Highway
}

\begin{abstract}
Tree-of-heaven (Ailanthus altissima (Mill.) Swingle) is a non-native invasive plant that is spreading throughout much of the U.S. In this study, efficacy of the herbicides triclopyr and imazapyr was tested using injection and basal bark treatment methods. No treatment was 100 percent effective. Only triclopyr injection was significantly different from other treatments, providing the least control. Both injection and basal spray treatments with imazapyr affected untreated neighbor stems, probably through root connections and/or root leaking. It is likely that seasonal or phenological timing of herbicide treatments may be more important in efficacy than treatment method or herbicide used.
\end{abstract}

\section{INTRODUCTION}

Originating in Southeast Asia, tree-of-heaven is now found on all continents except Antarctica (Udvardy 1998). In the Americas, tree-of-heaven can now be found from Massachusetts to Oregon and from Toronto to Argentina (Hu 1979). In some locations, it is so common that it appears to be a part of the native flora (Little 1979). It has been present in urban and agricultural settings for quite some time, often growing where no other tree would, but is now spreading into our forests, displacing more desirable native trees.

Possible control methods for tree-of-heaven include manual (hand pulling, digging, girdling), mechanical (chopping, cutting, mowing), burning, grazing, biocontrol, and chemical control (Hoshovsky 1988). A successful control method for tree-of-heaven kills the stems and roots while allowing for the reestablishment of native vegetation on the site (Burch and Zedaker 2003).

Chemical treatments are often performed on tree-of-heaven with differing levels of success. Foliar broadcast applications are effective in defoliating this species. Basal bark application may be used on trees up to six inches in diameter. For larger stems, cut stump treatments, treating fresh-cut stem surfaces with herbicide, may be effective (Randall and Martinelli 1996). A study of chemical control by Burch and Zedaker (2003) was successful in 
not only removing existing trees, but also somewhat successful in preventing resprouting and allowing for reestablishment of native vegetation on the site. Basal bark treatments with an herbicide combination including picloram (at least $5 \%$ of the product Tordon $\mathrm{K}$ ) proved most successful. Treatments of triclopyr ester, imazapyr, and a combination of the two herbicides all controlled $A$. altissima better than cutting, but were not as effective as treatments containing picloram.

The quandary is that the label for Tordon $\mathrm{K}$ (picloram) says, "Picloram is a chemical which can travel (seep or leach) through soil and under certain conditions has the potential to contaminate groundwater which may be used for irrigation and drinking purposes." Because of this, it may be advisable to formulate a prescription that does not include the use of picloram.

With the overall purpose of finding an herbicide treatment that can be used on the invasive tree-of-heaven growing in broadleaved stands in the central Appalachians, we established a study to investigate the efficacy of two commonly used herbicides used in combination with two herbicide application methods. The objective of this study was to test the efficacy of triclopyr or imazapyr applied by basal bark treatment or stem injection. Our secondary objective was to observe damage to non-target stems that may occur by means of root connections and seepage.

\section{METHODS}

\section{Study site}

The study was established in a 0.44 mile long plot centered on the Mile 150 marker along the northbound lane of I-79 in Morgantown, West Virginia. Several benches of shale and sandstone are present along most of this study site. Exposed bedrock-derived soils grade into 
forest soils on the north end of the site. Ailanthus is a clonal species, but most of this stand was contiguous and there were no discernable isolated clones.

\section{Herbicide treatments and application methods}

Imazapyr and triclopyr were the herbicides selected for use in this experiment. These are commonly-used forestry herbicides in many areas of North America, particularly in pine plantations of the Southeast.

Imazapyr inhibits the production of three chain amino acids necessary for plant growth and protein synthesis (Tu and others 2001). Mortality is largely dependent on the amount of stored amino acids. Roots begin to die soon after application followed by above ground growth cessation; mortality generally occurs one month after treatment (Cox 1996). Imazapyr is reported to be most effective during axillary budding (post-emergent) (Hanlon and Langeland 2000). Triclopyr behaves like a synthetic auxin, imitating the natural plant hormone indoleacetic acid and causing the growing tips of the plant to elongate, distort, wither, and die (Ware 2000). Triclopyr herbicide symptoms are likely caused by disorganized cell division that leads to vascular damage (WSSA 1994).

In the low volume basal bark treatments, the lower ten inches of stems were sprayed until thoroughly wet, including the root collar area, but not to the point of runoff. Garlon 4 (triclopyr ester) and Stalker (imazapyr) were used for the low volume basal bark treatment. Garlon 4 was mixed at 20 percent volume per volume in Aqumix basal bark oil, and Stalker at 8.5 percent (12 fluid ounces of Stalker in one gallon of penetrating oil). Because of the low volume of herbicide that was needed for this study, herbicide was applied with one liter spray bottles. These bottles were calibrated in the lab so that the volume of herbicide mixture used to treat each tree could be estimated. 
Stem injections were applied using the EZject ${ }^{\circledR}$ lance. The EZject inserts .22 caliber shells containing solid herbicide through the bark and into the cambium. Injections are applied to the lower ten inches of treated stems. Herbicides used in this method included imazapyr capsules (same active ingredient as Stalker) and triclopyr capsules (containing Garlon 3A; triclopyr amine). Triclopyr capsules contain $0.24 \mathrm{~g}$ active ingredient ( $0.27 \mathrm{~g}$ total), and imazapyr contain $0.18 \mathrm{~g}$ active ingredient $(0.24 \mathrm{~g}$ total). Label recommendations for injection rates are related to the size of the stem to be injected; one capsule per four inches (dbh) of circumference. The number of capsules to be injected was calculated prior to treatment to assure that each stem was injected with the recommended number of capsules.

\section{Treatment trees and associated vegetation}

During the summer of 2004, 150 tree-of-heaven stems were identified, mapped, and measured for use in this study. Diameter measurements were taken to assess treatment differences in efficacy of treatments by size class.

The four herbicide/application treatments were randomly applied to 30 trees each on August 4-5, 2004. Treatments 1 and 2 were low volume basal bark applications. Treatment 1 was $20 \%$ Garlon 4 (61.6\% triclopyr ester) in Aqumix penetrating oil and treatment 2 was $8.25 \%$ Stalker (27.6\% imazapyr) in Aqumix. Treatments 3 and 4 were EZject herbicide injection lance treatments. Treatment 3 was triclopyr (44.4\% triethylamine salt) capsule injection and treatment 4 was imazapyr (83.5\% imazapyr) capsule injection.

Thirty untreated control trees were also randomly chosen. A $2.25 \mathrm{~m}$ radius buffer was established around each subject tree to diminish the possibility of herbicide translocation between adjacent treatment trees. The two nearest living neighbor trees to each treated stem were marked, regardless of species, to monitor for herbicide translocation. 
Treatment stems were revisited in August 2005 (12 months after treatment (12MAT)) and were assigned a four-category efficacy score using the following qualitative ratings:

1- Tree was treated, but with no apparent negative effect on growth or health of the tree 2- Treatment effects evident with partial defoliation or retardation of foliage development 3- Defoliation complete, suckering or sprouting present

4- Defoliation complete, no evidence of suckering.

Table 1. Attributes of treated stems prior to and following herbicide treatments.

\begin{tabular}{lcccccc}
\hline & $\begin{array}{c}\text { Average } \\
\text { dbh } \\
\text { (in.) }\end{array}$ & $\begin{array}{c}\text { Average } \\
\text { Root } \\
\text { Suckers/Acre } \\
(\text { 12MAT) }\end{array}$ & $\begin{array}{c}\text { Average } \\
\text { Milliliters of } \\
\text { Herbicide per } \\
\text { Inch dbh }\end{array}$ & $\begin{array}{c}\text { Average } \\
\text { Number of } \\
\text { Capsules } \\
\text { per Stem }\end{array}$ & $\begin{array}{c}\text { Stems } \\
\text { Completely } \\
\text { Defoliated } \\
(\%)\end{array}$ & $\begin{array}{c}\text { Stems } \\
\text { with Root } \\
\text { Suckering } \\
(\%)\end{array}$ \\
\hline Treatment 1 & 3.05 & 4359 & 2.76 & & 90.0 & 13.3 \\
Treatment 2 & 2.95 & 9143 & 3.13 & & 80.0 & 40.0 \\
Treatment 3 & 3.35 & 1063 & & 2.63 & 3.3 & 10.0 \\
Treatment 4 & 3.13 & 1488 & & 2.47 & 93.3 & 6.7 \\
\hline
\end{tabular}

\section{Numerical methods}

A completely randomized analysis of variance was used to test for efficacy score differences among herbicide treatments. Diameter was included in the AOV as a potential source of variation in treatment efficacy. Dunnett's test was used as a mean separation procedure at the alpha $=0.05$ significance level.

\section{RESULTS AND DISCUSSION}

No treatment provided 100 percent control. Figure 1 shows the average efficacy of each treatment based on the qualitative ratings. Although the control trees were not treated with herbicide, five of them had suckers. This is not surprising, as clonal growth in tree-of-heaven is often a response to injury or stress to the parent plant (Kowarick 1995). The hot, dry shale slopes 
Figure 1--Comparison of average level of control for each treatment; level of control for Control was 1.33

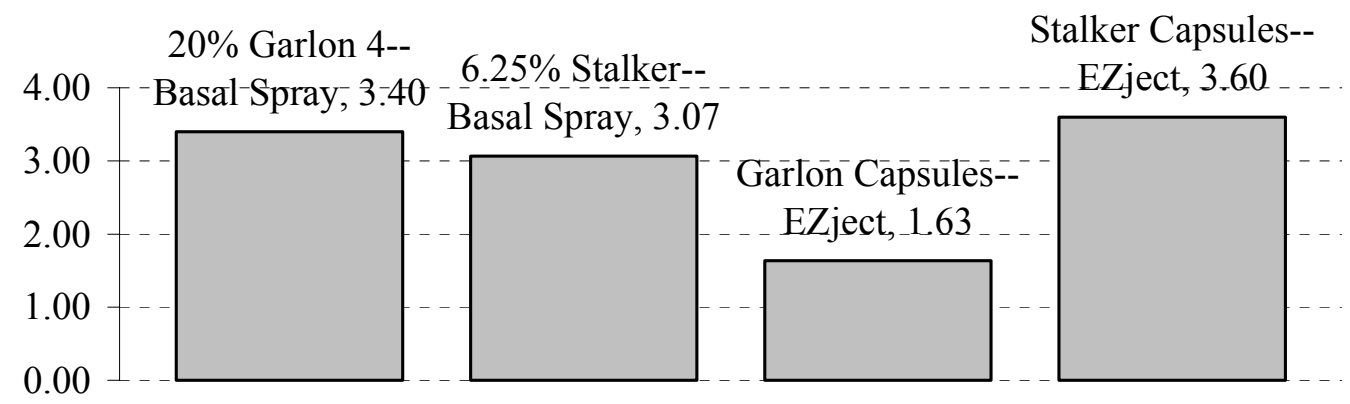

Level of Control

of the highway cut, on which this study is located, likely provide enough stress to invoke a small number of suckers, even in untreated stems. In fact, this site had many stems showing severe basal damage due to downslope soil and rock movement with significant bark and woody tissue damage on the uphill sides of these stems.

Table 2 shows the differences between the mean levels of control. No significant difference was found between efficacy of basal bark treatment of triclopyr and capsule injections of imazapyr. On average, they both provided topkill of stems but failed to kill the roots and suckering was present. These treatments provided the highest level of control. Triclopyr injection (treatment 3) provided the least control. In this treatment, treated trees showed little or no effect of herbicide treatment. A Dunnett's t test shows that the average level of control in treatment 3

Table 2. Fisher's LSD showing differences between mean level of control between treatments; means with the same letter are not significantly different

\begin{tabular}{ccccl}
\hline & & Mean Rating & $\mathrm{N}$ & \multicolumn{1}{c}{ Treatment } \\
\cline { 3 - 5 } & $\mathrm{A}$ & 3.60 & 30 & 4-Imazapyr capsule injection \\
$\mathrm{B}$ & $\mathrm{A}$ & 3.40 & 30 & 1-Garlon 4 (triclopyr) basal bark \\
$\mathrm{B}$ & & 3.07 & 30 & 2-Stalker (imazapyr) basal bark \\
& $\mathrm{C}$ & 1.63 & 30 & 3-Triclopyr capsule injection \\
\hline
\end{tabular}


Table 3. Dunnett's test comparing treatments to control; comparisons significant at the 0.05 level are indicated by *

\begin{tabular}{cccc}
\hline Treatment Comparison & Difference Between Means & \multicolumn{2}{c}{$95 \%$ Confidence Limits } \\
\hline 4 - Control & 2.60 & 2.59 & $3.81 *$ \\
1 - Control & 2.40 & 2.36 & $3.57 *$ \\
2 - Control & 2.07 & 1.93 & $3.14 *$ \\
3 - Control & 0.63 & -0.17 & 1.04 \\
\hline
\end{tabular}

was not significantly different from the untreated controls (table 3 ).

The average amounts of herbicide applied in the basal bark treatments to each inch of dbh (2.76 $\mathrm{ml}$ for Garlon 4 and $3.13 \mathrm{ml}$ for Stalker) was higher in the Stalker treatment. This difference does not seem to be important since the basal bark treatment of Garlon 4 actually had a higher average level of control, although the two treatments were not significantly different in efficacy (table 2).

Efficacy of treatment was significantly different between one-inch dbh classes (table 4). Level of control decreased significantly as diameter increased $(\mathrm{p}=0.004)$ (figure 2$)$. This is not surprising as treatments were applied to the bottom ten inches of the treatment stems while measurements and herbicide rate calculations were based on dbh. Because of often extreme taper between dbh and the larger tree bases, the number of capsules injected was likely less than the recommended one per four inches diameter.

Table 4. Fisher's LSD showing differences between mean level of control between 1" dbh classes; means with the same letter are not significantly different

\begin{tabular}{ccccc} 
& & Mean Rating & $\mathrm{N}$ & Dbh Class (in.) \\
\cline { 3 - 5 } & A & 3.27 & 26 & 1 \\
& A & 3.15 & 40 & 2 \\
B & A & 2.91 & 22 & 3 \\
B & C & 2.55 & 20 & 4 \\
& C & 2.08 & 12 & $5+$
\end{tabular}


Figure 2--Comparison of average level of control for each 1" dbh class

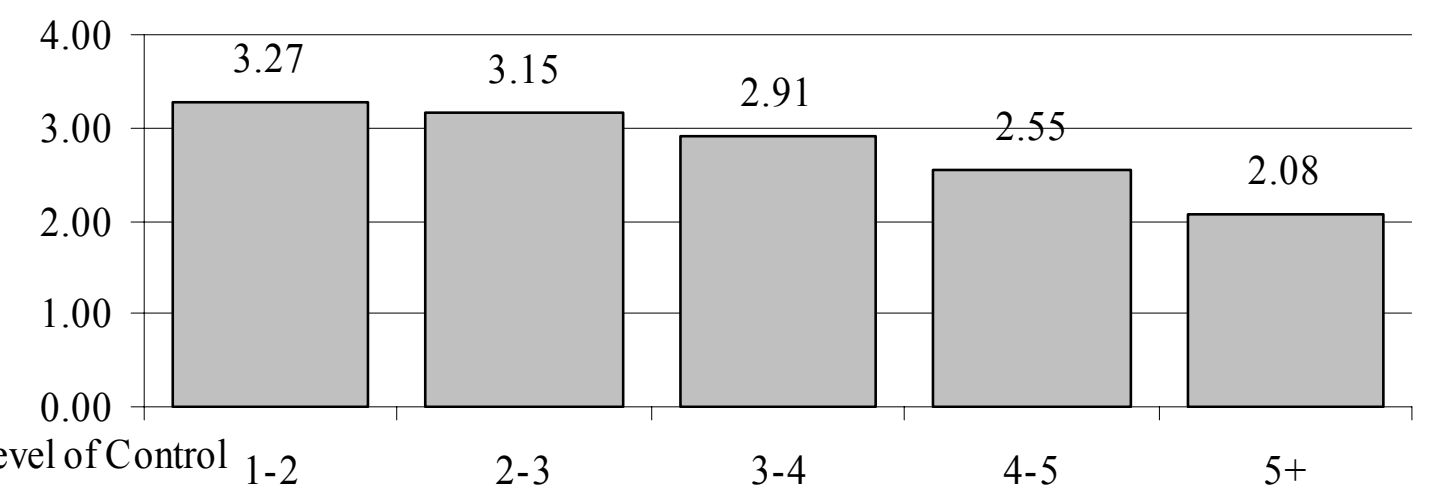

Diameter Class

Several non-target hardwood stems adjacent to imazapyr treated trees showed obvious signs of herbicide damage including wilting, prolific axillary budding, and chlorosis and necrosis of foliage. This affect was most common in tree-of-heaven stems (up to 15 feet from the treatment stem), but was also observed in black locust (Robinia pseudoacacia L.) and white ash (Fraxinus americana $\mathrm{L}$.) up to 48 inches from the treated stem. This is likely the result of root leakage, or root grafting between treated stems and those adjacent. No herbicide damage was observed in stems neighboring triclopyr treated stems.

Damage to untreated trees was not unexpected. In fact, the label for Stalker warns against possible damage to nontarget stems through root uptake. Imazapyr exhibits soil activity (Anderson 1996) and is known to be absorbed through the roots of plants outside of treated areas (USDA 1989). A study by Kochenderfer and others (2001) showed that in a herbicide hardwood crop tree release in central West Virginia, imazapyr treatments adversely affected several crop trees. On one site 66 percent of the crop trees were killed by imazapyr treatments. As in this study, they observed no nontarget damage in the triclopyr treatments. Herbicide damage to untreated trees caused by imazapyr is of importance as tree-of-heaven is becoming increasingly 
common in woodlots and forest gaps where this sort of damage is unwanted. More research needs to be conducted on damage to nontarget stems when using imazapyr.

\section{MANAGEMENT IMPLICATIONS}

No treatment in this study proved $100 \%$ effective in controlling tree-of-heaven by causing mortality to both the above ground and below ground portions of the tree. We recommend against the use of triclopyr injection since it was not significantly different in efficacy from untreated controls. Imazapyr injection was not significantly more effective in control than basal bark treatments with triclopyr. In areas with valuable crop trees or in mixed species stands, it is not advisable to use imazapyr treatments. In tree-of-heaven stands where a monoculture has formed, use of imazapyr treatments may be a useful strategy in achieving greater control.

It is likely that seasonal or phenological timing of herbicide treatments may be more important in efficacy than treatment method or herbicide used. Our treatments were performed in August which is late enough in the season that carbohydrate stores were likely restored from lowered levels just after full leaf expansion. A seasonal timing study in which these treatments were replicated several times throughout the growing season might show a treatment window with a higher level of control.

\section{REFERENCES}

Anderson, W.P. 1996. Weed science principles and applications. $3^{\text {rd }}$ edition. St.Paul, MN: West Publishing Company. 598p.

Bourke, C.A. 1996. Lack of toxicity of Ailanthus altissima (tree of heaven) for goats. Australian Veterinary Journal. 74(6):465.

Burch, P.L.; Zedaker, S.M. 2003. Removing the invasive tree Ailanthus altissima and restoring natural cover. Journal of Arboriculture. 29(1):18-24.

Cox,C. 1996. Imazapyr: Herbicide Factsheet. Journal of Pesticide Reform. 16(3):16-20.

Dillwyn, L.W. ed. 1843. Hortus Collinsoniansus. Swansea: privately published. p.2. 
Hanlon, C.G.; Langeland, K. 2000. Comparison of experimental strategies to control torpedograss. Journal of Aquatic Plant Management. 38:40-47.

Heptig, G.H. 1971. Diseases of Forest and Shade Trees of the United States. U.S. Dept. of Agric. U.S. Forest Service. Agriculture Handbook No. 386.

Hoshovsky, M.C. 1988. Element Stewardship Abstract: Ailanthus altissima (tree of heaven). The Nature Conservency. Arlington, VA. Available online: http://tncweeds.ucdavis.edu/esadocs/documnts/ailaalt.html

Hu, S.Y. 1979. Ailanthus. Arnoldia. 39(2):29-50.

Kochenderfer, J. K; Zedaker, S. M.; Johnson, J. E. [and others]. 2001. Herbicide crop tree release in central West Virginia. Northern Journal of Applied Forestry. 18(2):46-54.

Kowarick, I. 1995. Clonal growth in Ailanthus altissima on a natural site in West Virginia. Journal of Vegetation Science. 6:853-856.

Little, E.L. 1979. Checklist of United State Trees (Native and Naturalized). United States Department of Agriculture. Agricultural Handbook No. 541. p.47.

Miller, J.H. 1990. Ailanthus altissima (Mill.) Swingle. In: Burns, R.M and Honkala, B.H., technical coordinators. Silvics of North America: Volume 2 Hardwoods. United States Department of Agriculture Handbook 654. pp.101-104.

Mohonadas, K. and R.V. Verma. 1984. A new host record for Atteva fabriciella (Lepidoptera:Yponomeutidae) a pest of Ailanthus. Journal of Tree Science. 3(1/2):128.

Pannill, Philip. 1995. Tree-of-Heaven Control. Maryland Department of Natural Resources Forest Service Stewardship Bulletin. 8 pp. Online at: http://www.naturalresources.umd.edu/Pages/tree_of_heaven.htm

Randal, J.M.; Martinelli, J. 1996. Invasive Plants: Weeds of the Global Garden. Brooklyn, NY: Brooklyn Botanical Gardens. p.27.

Shah, B. 1997. The checkered career of Ailanthus altissima. Arnoldia. 57(3):20-27.

Tu, M., C. Hurd, and J.M. Randall. 2001. Weed Control Methods Handbook, The Nature Conservancy. Available online at: http://tncweeds.ucdavis.edu, version: April 2001.

Udvardy, L. 1998. Classification of adventives dangerous to the Hungarian natural flora. Acta Botanica Hungarica. 41:315-331.

USDA Forest Service. 1989. Vegetation management in the Appalachian Mountains. United States Department of Agriculture Forest Service. Vol. 1 Management Bulletin R8-MB38. 399pp.

Ware, G.W. 2000. The Pesticide Book, $5^{\text {th }}$ Ed. Fresno, CA: Thomson Publications. 415 p

WSSA. 2004. Herbicide Handbook. Champaign, Il: Weed Science Society of America. 


\title{
Chapter 2. Determining the Minimum Imazapyr Level Effective in Control of Tree-of-Heaven along a West Virginia Highway
}

\begin{abstract}
Tree-of-heaven (Ailanthus altissima (Mill.) Swingle) is a non-native invasive plant that is spreading throughout much of the U.S displacing natural vegetation. In this study, efficacy of triclopyr with different levels of imazapyr was tested using the basal bark treatment method. No treatment was 100 percent effective. Treatments of $20 \%$ triclopyr with $0.5,1,2$, and $3 \%$ imazapyr were not shown to be more effective than $20 \%$ triclopyr alone. It is likely that seasonal or phenological timing of herbicide treatments may be more important in efficacy than herbicide formulation.
\end{abstract}

\section{INTRODUCTION}

Originating in Southeast Asia, tree-of-heaven is now found on all continents except Antarctica (Udvardy 1998). In the Americas, the range of tree-of-heaven now extends from Massachusetts to Oregon and from Toronto to Argentina (Hu 1979). In some locations, it is so common that it appears to be a part of the native flora (Little 1979). It has been present in urban and agricultural settings for quite some time, often growing where no other tree would, but is now spreading into forests, displacing more desirable native trees.

A successful control method kills the stems and roots while allowing for the reestablishment of native vegetation on the site (Burch and Zedaker 2003). Possible control methods include manual (hand pulling, digging, girdling), mechanical (chopping, cutting, mowing), burning, grazing, biocontrol, and chemical control (Hoshovsky 1988). It is becoming common thought that chemical treatments may be the only practical prescription for heavily invaded areas. This is primarily because of the prolific sprouting and suckering that is exhibited after use of many of these control methods and the lack of a biocontrol agent that exclusively affects tree-of-heaven.

Chemical treatments are often implemented on tree-of-heaven with differing levels of success. The only successful treatment is one that not only top kills the tree, but also controls 
root and stump sprouting by translocating into the roots. Foliar broadcast applications are effective in defoliating this species. Basal bark application may be used on trees up to six inches. For larger stems, cut stump treatments, brushing fresh-cut stem surfaces with herbicide, may be effective (Randall and Martinelli 1996).

Using a combination of herbicides, Burch and Zedaker (2003) successfully controlled ailanthus and also somewhat successfully prevented resprouting, allowing for reestablishment of native vegetation on the site. Basal bark treatments that included picloram (at least $5 \%$ Tordon K) proved most successful. Treatments of Garlon 4 (triclopyr), Stalker (imazapyr), and a combination of Garlon 4 and Stalker all controlled ailanthus better than cutting, but were not as effective as treatments containing picloram.

Picloram, like most herbicides, must be used with caution. According to the label for Tordon K (picloram), "Picloram is a chemical which can travel (seep or leach) through soil and under certain conditions has the potential to contaminate groundwater which may be used for irrigation and drinking purposes."

If Garlon 4 (triclopyr ester) alone is not successful, perhaps it is necessary to add some level of Stalker (imazapyr) to attain 100 percent control. Treatments involving increased levels of imazapyr may also prove to be problematic. A study by Kochenderfer and others (2001) showed that in a hardwood crop tree release using herbicides in central West Virginia, imazapyr treatments adversely affected several crop trees.

The objectives of this study were to test the efficacy of chemical treatments for tree-ofheaven using different levels of imazapyr in combination with a set level of triclopyr in Aqumix penetrating oil, and to assess damage to non-target stems through root connections and seepage. Because a costly second treatment is needed when the root system is not killed and the treated 
trees are allowed to sucker and sprout, and because of the tendency of imazapyr to negatively affect non-target stems, finding the lowest amount of imazapyr necessary to achieve 100 percent control in one treatment without damaging non-target stems is desirable.

\section{METHODS}

\section{Herbicides}

Imazapyr and triclopyr were the herbicides selected for use in this experiment. These are commonly-used forestry herbicides in many areas of North America, particularly in pine plantations of the Southeastern U.S.

Imazapyr inhibits the production of three chain amino acids necessary for plant growth and protein synthesis (Tu and others 2001). Mortality of treated plants is largely dependent on the amount of amino acids they have stored. Roots begin to die soon after application followed by aboveground growth cessation; mortality generally occurs one month after treatment (Cox 1996). Imazapyr is reported to be most effective during axillary budding (post-emergent) (Hanlon and Langeland 2000).

Triclopyr behaves like a synthetic auxin, imitating natural plant hormones (e.g. indoleacetic acid) and causing the growing tips of the plant to elongate, distort, wither, and die (Ware 2000). Triclopyr herbicide symptoms are likely caused by disorganized cell division that leads to vascular damage (WSSA 1994).

\section{Treatments and assesment}

One hundred five stems were selected on a plot centered on Mile Post 138 along the southbound lane of I-79 just north of Fairmont, WV. This study included six treatments of 15 


\section{Table 1. Chemical treatments used to determine the minimum level of Stalker in combination with Garlon 4 necessary to provide $100 \%$ control of tree-of-heaven}

\begin{tabular}{ll}
\hline Treatment & Herbicide combinations $(\% \mathrm{v} / \mathrm{v})$ \\
\hline AQU & Aqumix \\
$\mathrm{T}$ & $20 \%$ Garlon 4 in Aqumix \\
$\mathrm{T}+\mathrm{I} 0.5$ & $20 \%$ Garlon $4+0.5 \%$ Stalker in Aqumix \\
$\mathrm{T}+\mathrm{I} 1$ & $20 \%$ Garlon $4+1 \%$ Stalker in Aqumix \\
$\mathrm{T}+\mathrm{I} 2$ & $20 \%$ Garlon $4+2 \%$ Stalker in Aqumix \\
$\mathrm{T}+\mathrm{I} 3$ & $20 \%$ Garlon $4+3 \%$ Stalker in Aqumix \\
\hline
\end{tabular}

trees (table 1), and a control group. All herbicide formulations were applied using a low volume basal bark application in which the lower ten inches of stems, including the root collar area, were sprayed until thoroughly wet, but not to the point of runoff. Garlon 4 was mixed at 20 percent in Aqumix basal bark oil, and Stalker was added at varying levels by treatment. Because of the low volume of herbicide that was need for this study, herbicide was applied with one liter spray bottles. These bottles were calibrated in the lab so that the volume of herbicide mixture used to treat each tree could be determined.

Treatments were applied in August 2004. A 2.25m radius buffer was established around each subject tree to guard against potential herbicide translocation between subject trees and to observe mobility of herbicides to neighboring stems. For the latter purpose, the two nearest living neighbor trees were marked for observation and monitoring. Diameter measurements were taken to asses differences in efficacy of treatments by size class.

Diameter measurements were taken to account for treatment differences due to tree size. Efficacy of treatments was assessed in August 2005 (12 months after treatment (12MAT)) using the following qualitative ratings:

1- No apparent negative effect on growth or health of the tree

2- Treatment effects are evident, partial defoliation or retardation of foliage, no suckering

3- Defoliation is complete, suckering or sprouting is present

4- Defoliation is complete and there is no evidence of suckering 
Table 2. Comparisons of different aspects of treatment efficacy

\begin{tabular}{ccccc}
\hline Treatment & $\begin{array}{c}\text { Average dbh } \\
\text { (in.) }\end{array}$ & $\begin{array}{c}\text { herbicide mixture } \\
\text { (ml/in dbh) }\end{array}$ & $\begin{array}{c}\text { Topkill } \\
(\%)\end{array}$ & $\begin{array}{c}\text { Stems w/ root suckers } \\
(\%)\end{array}$ \\
\hline AQU & 1.95 & 4.00 & 60.00 & 60.00 \\
T & 2.13 & 3.79 & 100.00 & 80.00 \\
T+I0.5 & 1.96 & 4.08 & 100.00 & 60.00 \\
T+I1 & 2.16 & 4.00 & 86.67 & 46.67 \\
T+I2 & 2.06 & 4.18 & 93.33 & 73.33 \\
T+I3 & 2.15 & 4.26 & 100.00 & 87.50 \\
\hline
\end{tabular}

\section{RESULTS AND DISCUSSION}

Diameters of treatment and control trees in this study ranged from 1.01 to 3.86 inches.

Table 2 shows the average diameter for each treatment. An analysis of variance shows that diameters were not significantly different between treatments $(p=0.929)$ and efficacy of treatments was not significantly different between 1 " dbh classes $(p=0.764)$. No significant difference was found between the average amounts of herbicide applied to each inch of dbh between treatments $(p=0.767)($ table 2$)$.

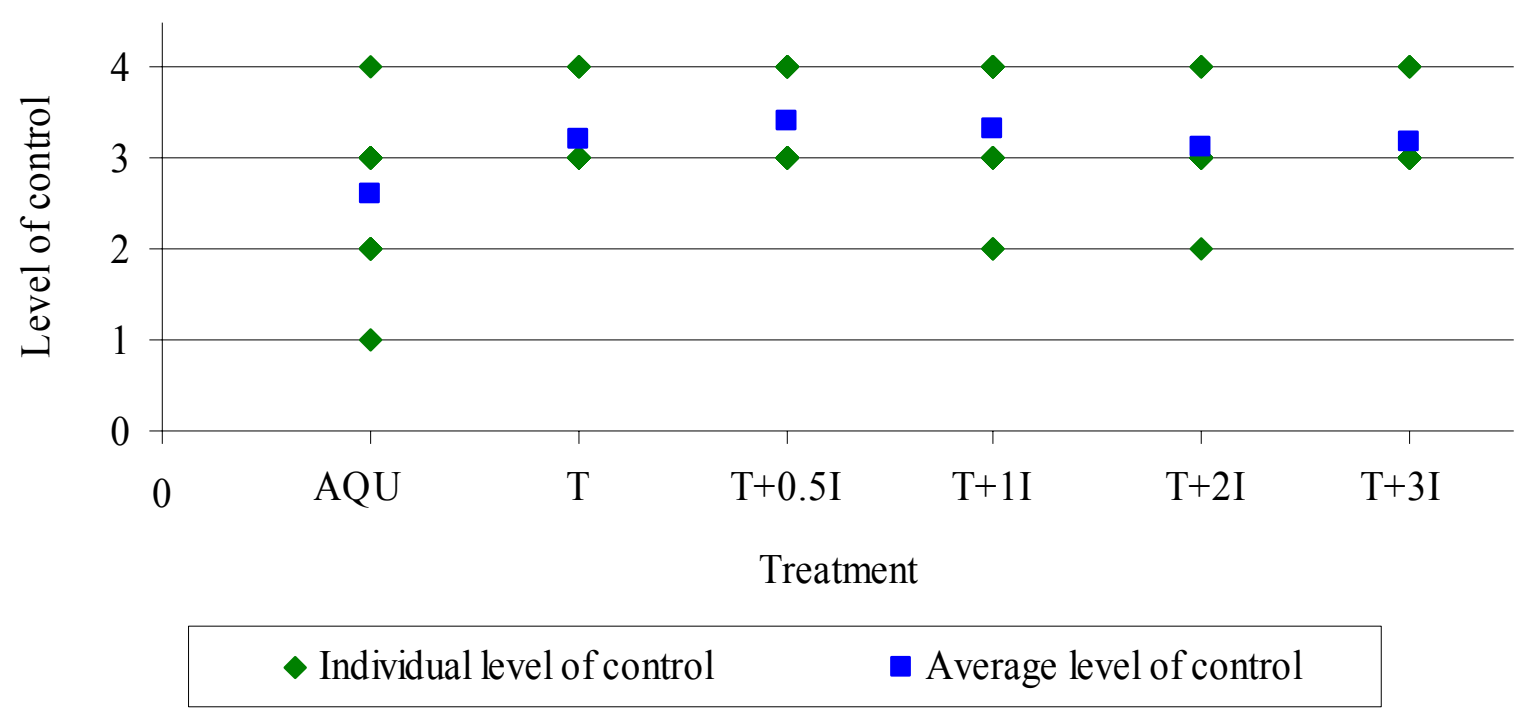

Figure 1--Comparison of average level of control for each treatment 
No treatment provided 100 percent control.

Figure 1 shows the average efficacy of each

treatment based on the qualitative ratings. An

analysis of variance shows a significant difference

in efficacy between treatments $(\mathrm{p}=0.003)$.

Treatment 1 (Aqumix only) was significantly

different from all of the herbicide treatments. No

Table 3. Fisher's LSD for mean levels of control

\begin{tabular}{lll}
\hline Treatment & $\mathrm{N}$ & \multicolumn{2}{c}{ Mean Rating* } \\
\hline $\mathrm{AQU}$ & 15 & $2.60 \mathrm{a}$ \\
$\mathrm{T}$ & 15 & $3.20 \mathrm{~b}$ \\
$\mathrm{~T}+\mathrm{I} 0.5$ & 15 & $3.40 \mathrm{~b}$ \\
$\mathrm{~T}+\mathrm{I} 1$ & 15 & $3.33 \mathrm{~b}$ \\
$\mathrm{~T}+\mathrm{I} 2$ & 15 & $3.13 \mathrm{~b}$ \\
$\mathrm{~T}+\mathrm{I} 3$ & 15 & $3.19 \mathrm{~b}$ \\
\hline *means with the same letter are not \\
significantly different
\end{tabular}

significant difference was found between any of the

other five treatments (table 3). This shows that efficacy of Garlon 4 treatments is not improved with addition of $0.5,1,2$, or $3 \%$ Stalker. A Dunnett's $t$ was performed to verify that each of the treatments was different than the untreated controls. Surprisingly, AQU (Aqumix only) was different from the control (table 4).

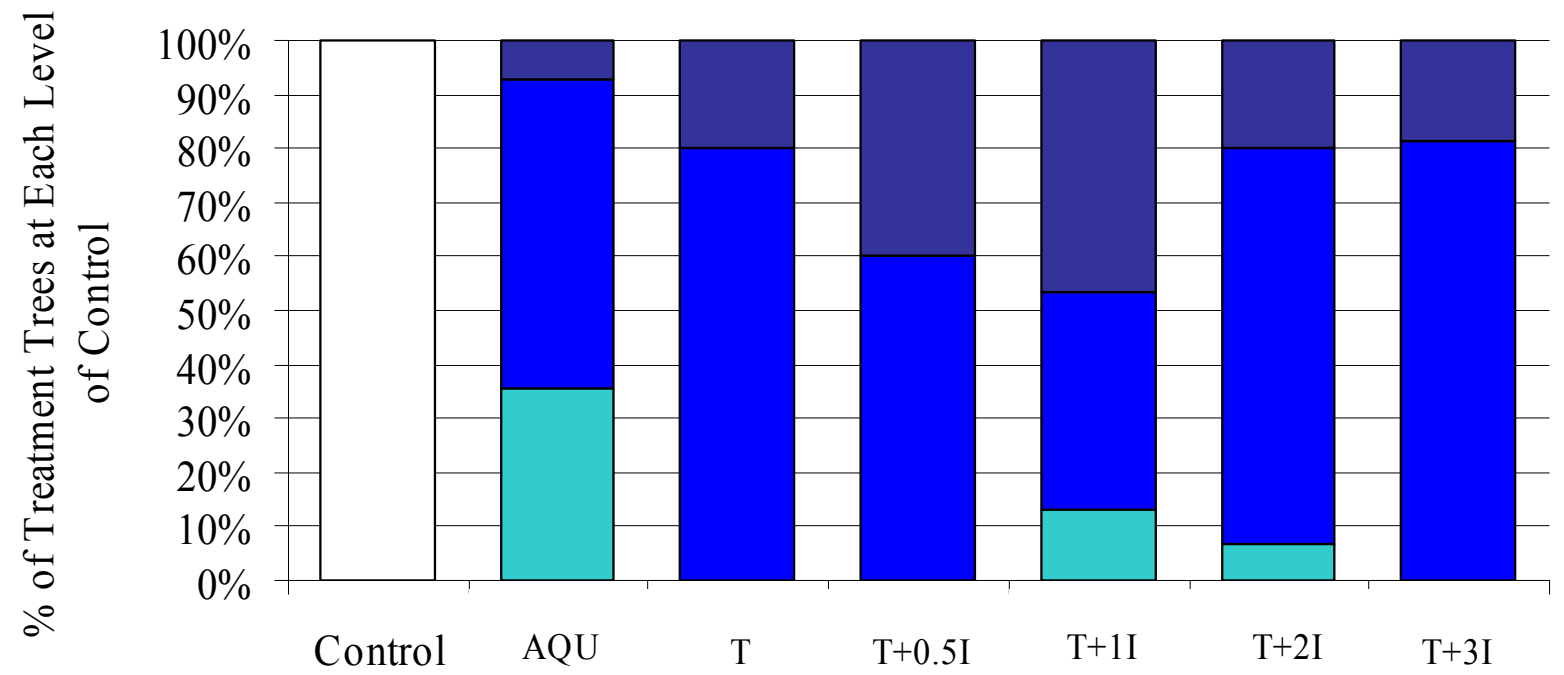

Level of Control

Treatment

Figure 2. Percentage of trees at each level of control between treatments 


\section{Table 4. Dunnett's t comparing treatments to control; comparisons significant at the 0.05 level are indicated by *}

\begin{tabular}{lcrrr}
\hline & Difference Between & \multicolumn{3}{c}{$95 \%$ Confidence } \\
Treatment Comparison & Means & \multicolumn{3}{c}{ Limits } \\
\hline T+I0.5 - Control & 2.40 & 1.89 & 2.91 & $*$ \\
T+I1 - Control & 2.33 & 1.82 & 2.84 & $*$ \\
T - Control & 2.20 & 1.69 & 2.71 & $*$ \\
T+I3 - Control & 2.19 & 1.69 & 2.69 & $*$ \\
T+I2 - Control & 2.13 & 1.62 & 2.64 & $*$ \\
AQU - Control & 1.60 & 1.09 & 2.11 & $*$ \\
\hline
\end{tabular}

While no significant difference was found between herbicide treatments, $\mathrm{T}+\mathrm{I} 1$ and $\mathrm{T}+\mathrm{I} 2$ appear to be worse than Garlon 4 alone if top-killing tree-of-heaven is your primary goal (table 2, figure 2). The highest level of sprouting was exhibited in $\mathrm{T}+\mathrm{I} 3$ (table 2) which included the highest level of added imazapyr. More sprouting with additional herbicides is puzzling, but should be reason enough to leave imazapyr out of triclopyr treatments for tree-of-heaven.

Although the control trees were not treated with herbicide, four (26.7\%) had suckers. Clonal growth in tree-of-heaven is often a response to injury or stress to the parent plant (Kowarik 1995). The hot, dry shale slopes of the highway cut on which this study is located likely provide enough stress to invoke a small number of suckers, even in untreated stems.

While some damage was observed to untreated nearest neighbor trees in association with treatments involving imazapyr, this relationship did not prove to be significant. $(\mathrm{p}=0.195)$ It is important to note however that several non-target hardwood stems adjacent to imazapyr treated trees showed obvious signs of herbicide damage including wilting, prolific axillary budding, and chlorosis and necrosis of foliage. Damage to untreated trees was not unexpected. In fact, the Stalker label warns against damge to nontarget stems through root uptake. Imazapyr exhibits soil activity (Anderson 1996) and is known to be absorbed through the roots of plants outside of treated areas (USDA 1989). Herbicide damage to untreated trees caused by imazapyr is of 
importance as tree-of-heaven is becoming increasingly common in woodlots and forest gaps where nontarget damage could prove to be both ecologically and economically costly. On the same note, in stands of Ailanthus altissima where a monoculture has formed, it may be a useful strategy in achieving greater control. More research is needed on the flashback effects of imazapyr on untreated trees.

\section{MANAGEMENT IMPLICATIONS}

Achieving $100 \%$ control in a single treatment while using the lowest level of added imazapyr to triclopyr was the primary objective of this study. While this objective was not met, it is interesting to note that addition of Stalker does not improve the efficacy of Garlon 4 treatments in controlling tree-of-heaven.

It is likely that seasonal or phenological timing of herbicide treatments may be more important in efficacy than treatment method or herbicide used. Our treatments were performed in August which is late enough in the season that carbohydrate stores were likely restored from lowered levels just after full leaf expansion. A seasonal timing study in which these treatments were replicated several times throughout the growing season might show a treatment window with a higher level of control.

\section{REFERENCES}

Anderson, W.P. 1996. Weed science principles and applications. $3^{\text {rd }}$ edition. St.Paul, MN: West Publishing Company. 598p.

Burch, P.L.; Zedaker, S.M. 2003. Removing the invasive tree Ailanthus altissima and restoring natural cover. Journal of Arboriculture. 29(1):18-24.

Cox,C. 1996. Imazapyr: Herbicide Factsheet. Journal of Pesticide Reform. 16(3):16-20.

Hanlon, C.G.; Langeland, K. 2000. Comparison of experimental strategies to control torpedograss. Journal of Aquatic Plant Management. 38:40-47.

Hoshovsky, M.C. 1988. Element Stewardship Abstract: Ailanthus altissima (tree of heaven). The Nature Conservency. Arlington, VA. Available online:

http://tncweeds.ucdavis.edu/esadocs/documnts/ailaalt.html 
Hu, S.Y. 1979. Ailanthus. Arnoldia. 39(2):29-50.

Kochenderfer, J. K; Zedaker, S. M.; Johnson, J. E. [and others]. 2001. Herbicide crop tree release in central West Virginia. Northern Journal of Applied Forestry. 18(2):46-54.

Kowarik, I. 1995. Clonal growth in Ailanthus altissima on a natural site in West Virginia. Journal of Vegetation Science. 6:853-856.

Little, E.L. 1979. Checklist of United States Trees (Native and Naturalized). United States Department of Agriculture. Agricultural Handbook No. 541. p.47.

Randal, J.M.; Martinelli, J. 1996. Invasive Plants: Weeds of the Global Garden. Brooklyn, NY: Brooklyn Botanical Gardens. p.27.

Tu, M., C. Hurd, and J.M. Randall. 2001. Weed Control Methods Handbook, The Nature Conservancy. Available online at: http://tncweeds.ucdavis.edu, version: April 2001.

Udvardy, L. 1998. Classification of adventives dangerous to the Hungarian natural flora. Acta Botanica Hungarica. 41:315-331.

USDA Forest Service. 1989. Vegetation management in the Appalachian Mountains. United States Department of Agriculture Forest Service. Vol. 1 Management Bulletin R8-MB38. 399pp.

Ware, G.W. 2000. The Pesticide Book, $5^{\text {th }}$ Ed. Fresno, CA: Thomson Publications. 415 pp.

WSSA. 2004. Herbicide Handbook. Champaign, Il: Weed Science Society of America. 


\section{Chapter 3. Developing Treatment Windows through Timing of Chemical Controls for Tree-of-Heaven in West Virginia}

\section{INTRODUCTION}

Biological invasions of exotic species are the leading causes of recent extinction and one of the main causes of endangerment of species, second only to habitat destruction (Vitousek et al., 1997). They have been shown to increase carbon assimilation rates (Le Maitre et al. 1996), change soil nutrient status (Vitousek and Walker, 1989), increase flammability (Anable et al., 1992), threaten native species (Musil 1993; Meyer and Florence 1996), change habitat suitability for native animal species (Steenkamp and Chown 1996; Allan et al., 1997), and bring about substantial negative economic consequences (Higgins et al., 1999). A growing body of work shows that non-indigenous invasive species can decrease native biodiversity and alter ecosystem functioning (Vitousek and Walker 1989; D'Antonio and Vitousek, 1992; Schmitz, et al. 1997; Walker and Steffen, 1997; Parker and Reichard, 1998).

The tree-of-heaven (Ailanthus altissima (Mill.) Swingle) which originated in Asia is a non-native invasive tree that now threatens natural flora and fauna across the globe (Call and Nilson 2003) and can now be found on all continents except Antarctica (Udvardy, 1998). In the Americas, tree-of-heaven now exists from Massachusetts to Oregon and from Toronto to Argentina (Hu 1979). In some locations, tree-of-heaven is so common that it appears to be a part of the native flora (Little 1979).

Many control methods for tree-of-heaven have been researched including manual (hand pulling, digging, girdling), mechanical (chopping, cutting or mowing), burning, grazing, biocontrol, and chemical (Hoshovsky, 1988). It is commonly thought, however, that herbicide treatments may be the only practical control method for heavily invaded areas because of 1 ) the 
prolific sprouting and suckering that occurs following treatment of tree-of-heaven using many of these other control methods and 2) the lack of a biocontrol agent that exclusively attacks tree-ofheaven.

Research investigating herbicide treatments of tree-of-heaven has been conducted with differing levels of success. A successful treatment is one that not only top kills the tree, but also controls root and stump sprouting. Foliar broadcast applications are effective in defoliating this species. Basal bark application may be used on trees up to six inches in diameter. Cut stump treatments, brushing fresh-cut stem surfaces with herbicide, may be effective for larger stems (Randall and Martinelli 1996).

Using a combination of herbicides, Burch and Zedaker (2003) successfully controlled tree-of-heaven and also somewhat successfully prevented resprouting, allowing for reestablishment of native vegetation on the site. Basal bark treatments that included picloram (at least 5\% Tordon K) proved most successful. Treatments of Garlon 4 (triclopyr), Stalker (imazapyr), and a combination of Garlon 4 and Stalker all controlled tree-of-heaven better than cutting, but were not as effective as treatments containing picloram.

Picloram, like most herbicides, must be used with caution. According to the label for Tordon K (picloram), "Picloram is a chemical which can travel (seep or leach) through soil and under certain conditions has the potential to contaminate groundwater which may be used for irrigation and drinking purposes."

On the same note, imazapyr exhibits soil activity (Anderson 1996) and is known to be absorbed through the roots of plants outside of treated areas (USDA 1989). A study by Kochenderfer and others (2001) showed that in a hardwood crop tree release using herbicides in central West Virginia, imazapyr treatments adversely affected several crop trees. On one site, 66 
percent of the crop trees were killed by imazapyr treatments, but no nontarget damage was observed in their triclopyr treatments. These attributes of picloram and imazapyr make the herbicides unsuitable for use on tree-of-heaven in close proximity to valuable broadleaved trees. As an alternative to treatments including either picloram or imazapyr, a prescription that provides $100 \%$ control of both the above ground, and below ground portions of the tree using an herbicide with less soil activity is desirable. Triclopyr is commonly used in various forestry applications and has limited mobility and low to medium persistence in soil. It dissipates via multiple pathways, such as photolysis, plant metabolism, and microbial degradation so its potential to leach to depths in soil and to contaminate groundwater is low (Cessna et al., 2002). Triclopyr has no soil activity at registered rates (WSSA, 2004) and poses little risk to associated vegetation. The mode of action for triclopyr is behavior as a synthetic auxin, imitating natural plant hormones such as indoleacetic acid and causing the growing tips of the plant to elongate; followed by distortion, withering, and death (Ware 2000). It is rapidly transported in plants, primarily via the symplastic pathway (including the phloem) and accumulates at growing points (WSSA, 2004).

The primary objective of this study was to refine herbicide timing recommendations for Garlon 4 basal bark applications on tree-of-heaven in an attempt to avoid addition of picloram, imazapyr, or other more readily soil mobile herbicides. The study also aimed to characterize the seasonal growth patterns of tree-of-heaven as such information is currently not available in the eastern United States. 


\section{METHODS}

\section{Study Site}

The site for this study was an area of approximately one hectare on the Crawford Tree Farm near Fairmont, West Virginia. In 1998, two years following a partial timber harvest that left approximately 100 high-quality residual trees per hectare, a severe microburst of wind toppled or severely damaged these residuals and led to a salvage harvest to recover merchantable trees. In the years following the original timber harvest, the forester administering the timber sale observed a significant population of yellow-poplar (Liriodendron tulipifera L.) seedlings. Following the blow-down and subsequent salvage operation this yellow-poplar reproduction was reduced in abundance and several locations in the newly-disturbed area were invaded by tree-ofheaven seedlings. This study focuses on controlling these now 5-6 year-old tree-of-heaven saplings.

There are two soil series on this site; Culleoka-Westmoreland silt loam (CwE) and a Clarksburg silt loam (CkD). CwE is a steep, well-drained, moderately deep (20 to 40 inches) soil with $25-30 \%$ slopes. CkD is a moderately steep, moderately well-drained, deep ( $>60$ inches) soil with $15-25 \%$ slopes. Both of these soils have a moderately high potential productivity for trees. (NRCS, 1977)

\section{Vegetation sampling}

In April 2004, an inventory of the sapling, seedling and herbaceous vegetation was conducted to help characterize this site. All trees greater than $1.37 \mathrm{~m}$ (breast height) were tallied on $16 \mathrm{~m}^{2}$ circular plots to determine stand sapling composition. The site is dominated by tree-ofheaven making up $66.9 \%$ of the sapling layer with nearly 5000 trees per hectare (table 1). Apart from tree-of-heaven, only sugar maple (Acer saccharum) contributed more than $10 \%$ to the 
sapling layer. Heights were measured using an eight meter telescoping height pole. Tree-ofheaven sapling were, on average, more than a meter taller than any other species.

Herbaceous cover was also recorded on each $16 \mathrm{~m}^{2}$ circular plot. A list was continuously generated throughout the inventory and species presence/absence was recorded on each plot. Table 2 shows the herbaceous cover found on over $50 \%$ of study plots.

Seedlings (less than $1.37 \mathrm{~m}$ height) were tallied on $2 \mathrm{~m}^{2}$ circular plots. Sugar maple dominated the seedling layer accounting for $72 \%$ of seedlings with 28,780 per hectare (table 3 ). Tree-of-heaven makes up only $2.3 \%$ of this layer showing poor recruitment under the heavy shade of the dense regenerating saplings and shrubs.

\section{Herbicide Treatments}

One hundred twenty-two dominant and codominant tree-of-heaven stems were selected for use in the herbicide experiment. A $2.25 \mathrm{~m}$ radius buffer $\left(16 \mathrm{~m}^{2}\right)$ was observed around each subject tree to avoid effects of herbicide translocation between subject trees and to maintain an adequate buffer for observing possible mobility of herbicide to adjacent stems. The 122 study trees were randomly assigned a date for treatment, or designated as one of ten untreated control trees. Twenty-three treatments were conducted weekly throughout the growing season, with the remaining five being spread equally through the dormant season.

Four trees were treated in each treatment week using low-volume basal bark treatments with 20\% Garlon $4(\mathrm{v} / \mathrm{v})$ in Aqumix oil. In the basal bark treatment, the lower ten inches of stems were sprayed until thoroughly wet, including the root collar area, but not to the point of runoff. Garlon 4 can be applied in any season when using a low volume basal bark application, except when snow or water prevent spraying to the ground line or when stem surfaces are saturated with water. Treatments were applied with one liter plastic squirt bottles which had been calibrated in 
the lab so that the volume of herbicide mixture used to treat each tree could be determined.

Herbicide volume applied was recorded by counting number of squirts of known volume.

Tree defoliation, control, and mortality percentages and presence of root suckers were recorded in August 2005 (12 months after treatment (12MAT)). Efficacy of treatments was rated using the following qualitative ratings:

1- No apparent negative effect on growth or health of the tree

2- Treatment effects are evident, partial defoliation or retardation of foliage

3- Defoliation is complete, suckering or sprouting is present

4- Defoliation is complete and there is no evidence of suckering; mortality

Precipitation and temperature data was obtained from the closest local weather station at the Morgantown Municipal Airport to determine if the weather during the treatment year was consistent with an average year in this area.

Height and dbh of the controls were measured every week throughout the 2004 growing season (13-Apr to 27-Oct). Because different sized and aged trees grow at different rates, all height and diameter data was standardized to remove the size dependent growth factor.

\section{Numerical Methods}

All analysis was performed in SAS 9.1. Data was analyzed using ANOVA with Proc GLM and means were separated by LSD. Correlation analysis was performed using Proc CORR. All analysis was performed at the $\alpha=0.05$ significance level.

\section{RESULTS}

Weather data was compiled and compared with historical weather data for the region to assure that weather in the treatment year was not abnormal. When compared with monthly temperature and precipitation data from the previous eight years, only August, October and January had significantly different weather in the treatment year. Each of these months had higher than average precipitation in 2004-2005. Mean temperature was not significantly 
different in any month of the treatment year than the average monthly mean temperatures of the previous eight years. (table 4)

\section{Seasonal growth patterns of tree-of-heaven}

Untreated controls grew an average of $0.76 \mathrm{~cm}$ in diameter and $1.11 \mathrm{~m}$ in height over the 2004 growing season. Figure 1 shows the weekly diameter and height increments. Height growth began in late April and peaked soon after in mid-May. Diameter growth began in early April, peaking in mid-June.

Correlation was calculated between weekly growth increments and weekly precipitation during the growing season. Height increment was not correlated to precipitation $\left(\mathrm{R}^{2}=0.026\right.$, $\mathrm{p}=0.5355)$, but weekly diameter growth increment was $\left(\mathrm{R}^{2}=0.378, \mathrm{p}=0.0065\right)$. Weekly precipitation explains about $38 \%$ of the variability in weekly diameter growth. In general, diameter growth was greater in weeks with higher precipitation (figure 2)

\section{Effects of timing on efficacy of basal bark treatments}

All stems treated with $20 \%$ Garlon 4 in basal oil were completely defoliated and top-

killed. This eliminated the need for efficacy ratings 1 (no apparent negative effect) and 2 (partial defoliation). Treated trees were assessed solely on presence of root suckers. Efficacy rating differed by week of control $(\mathrm{p}=0.028)$. In general, treatments applied during the peak of the growing season were significantly different from those in the dormant season (figure 3).

Average weekly diameter increment differed significantly between weeks with different treatment effectiveness $(\mathrm{p}=0.0005)$. Weeks with no sprouting had significantly higher average weekly diameter growth increments than any weeks in which sprouting occurred (figure 4). 


\section{DISCUSSION}

With respect to tree-of-heaven, the ideal treatment is one that not only top kills the tree, but also controls root and stump sprouting. This means that only the weeks in figure 3 when no sprouting occurred did ideal treatments result. In this study $100 \%$ control was exhibited from May 31 to July 12, therefore we recommend that all treatments be performed in June or early July.

To our knowledge there are no published studies of timing of herbicide treatment for treeof-heaven, and certainly none that involve weekly treatments. Studies of herbicide timing on other species are common, and treatment windows for these species were not always similar. A study on herbicide timing of Chinese privet (Ligustrum sinense Lour.) by Harrington and Miller (2005) found that treatments in April, October, and December were more effective than those in June and August. Lym and Messersmith (1994) found that the most effective timing for control of Leafy Spurge (Euphorbia esula L.) was in the spring. Timing may also depend on the herbicide used for control. Control of perennial pepperweed (Lepidium latifolium L.) and hoary cress (Cadaria draba L. Desv.) was effective in spring, summer, and autumn with sulfonylurea herbicides (Drake and Whitson, 1989; Whitson et al., 1989; Young, et al. 1998), while control with glyphosate was best in spring (Waterhouse and Mahoney, 1983; Young, et al. 1998).

August, October, and January of the treatment year had significantly higher mean precipitation in the treatment year than in the previous eight years. This does not affect our proposed treatment window of June 1-July 12 since precipitation and temperatures for June, July, and the preceding months were not significantly different from the 8 previous years.

The Garlon 4 label contains wording that suggests dormant stem treatments will control susceptible woody plants and vines with stems less than two inches in diameter, and that plants with stems greater than two inches in diameter may not be controlled and resprouting may occur. 
In this study, all trees treated in the dormant season were less than two inches $\mathrm{dbh}$, and $75 \%$ of trees treated in the dormant season sprouted.

During the growing season, weeks with higher precipitation, generally had higher weekly diameter growth increments. In this study, precipitation explained $38.9 \%$ of the variability in weekly diameter increment. The remainder of the variability may be explained by unmeasured factors such as competition. We also found a significant difference in average weekly growth increment at different levels of treatment effectiveness with less sprouting occurring in weeks with higher diameter growth increments. One could draw the conclusion that since diameter growth is highest when precipitation is highest throughout the growing season, and treatments are most effective when plants are growing at the highest rate, treatments should not be performed during dry spells when growth rates will likely be low. Triclopyr is phloem mobile (WSSA, 2004). If photosynthesis is active, the flow of photosynthate and phloem mobile herbicide is strong (Ashton and Crafts, 1973). If photosynthesis is weak, while the plant is drought stressed, for example, the flow of phloem mobile herbicide decreases or stops because phloem transport is reduced (Balneaves, 1985).

While we did not have $100 \%$ control of stems, our treatments defoliated all treated stems, and a cheaper follow up application could be performed on sprouts. There was a high density of sugar maple and other saplings, but with average heights of only $1.5-2.5 \mathrm{~m}$ they are probably not tall enough to out-compete new tree-of-heaven sprouts which have been shown to grow an average of one meter per year (Illick and Brouse, 1926).

If no control practices for tree-of-heaven were performed, it would likely continue to dominate this stand for many years. Tree-of-heaven saplings averaged more than one meter taller than any other species on the site. This may be a result of the relatively fast growth rate of 
tree-of-heaven (Heisey, 1990) and the unpalatability of this species to white tailed deer

(Forgione, 1993). Tree-of-heaven could have a significant advantage by means of the high deer population in this area, as unpalatable species often do (Knapp and Canham, 2000). It is likely that all of these stems were recruited in the stand after the blow-down event in 1998 and the subsequent salvage harvest, not a result of advanced regeneration. With treatment of tree-ofheaven saplings, this stand would likely develop into a diverse Central Hardwoods stand.

\section{MANAGEMENT IMPLICATIONS}

In this study $100 \%$ control was exhibited from May 31 to July 12, therefore we recommend that all treatments be performed in June or early July using a low volume basal bark application of $20 \%$ Garlon $4(\mathrm{v} / \mathrm{v})$ in Aqumix oil. This recommendation is based on a single season, single site study, that was replicated weekly. Future studies should examine timing through many growing seasons and on a variety of sites. The recommended treatment window will need to be modified to fit different regions because phenological patterns differ by geographic region and latitude.

With Rubus spp. on $90 \%$ of the study plots, often at $100 \%$ cover, access to treatment trees was very difficult. This would make an effective treatment window in the dormant season desirable. Treatments of Garlon 4 at $20 \%$ in oil were successful in defoliating tree-of-heaven in this study during the dormant season. If defoliation is the management goal, applications of this formula at any period through the year would likely prove effective.

\section{AKNOWLEDGEMENTS}

Thanks for help in data collection and treatments to Dheeraj Nelli, Matther Kosydar, and John Pomp. Garlon 4 is a trademarks of Dow Agrosciences, LLC. Stalker is a trademark of BASF. Aqumix is a trademark of Aqumix, Inc. Cloverdale, VA. 


\section{REFERENCES}

Allan, D.G., J.A. Harrison, R.A. Navarro, B.W. van Wilgen, and M.W. Thompson. 1997. The impact of commercial afforestation on bird populations in Mpumalanga province, South Africa: insights form bird-atlas data. Biological Conservation. 79:173-185.

Anable, M.E., M.P. McClaren, G.B. Ruyle. 1992. Spread of introduced Lehmann lovegrass Eragrostis tehmanniana Nees. in southern Arizona. Biological Conservation. 61:181-188.

Anderson, W.P. 1996. Weed science principles and applications. $3^{\text {rd }}$ edition. St.Paul, MN: West Publishing Company. 598p.

Ashton, F.M. and A.S. Crafts. 1973. 1973 Mode of action of herbicides. John Wiley \& Sons, Inc., New York.

Balneaves, J.M. 1980. Effect of herbicides on gorse in a dry year. Proceedings of the $33^{\text {rd }}$ New Zealand Weed and Pest Control Conference. 38:92-93.

Burch, P.L.; Zedaker, S.M. 2003. Removing the invasive tree Ailanthus altissima and restoring natural cover. Journal of Arboriculture. 29(1):18-24.

Call, L.J., and E.T. Nilson. 2003. Analysis of Spatial Patterns and Spatial Association between the Invasive Tree-of-Heaven (Ailanthus altissima) and the Native Black Locust (Robinia pseudoacacia). American Midland Naturalist. 150:1-14

Cessna, A.J.; Grover, R.; Waite, D.T. 2002. Environmental fate of triclopyr. Reviews of Environmental Contamination and Toxicology. 174:19-48.

D’Antonio, C.M. and P.M. Vitousek. 1992. Biological invasions by exotic grasses, the grass/fire cycle, and global change. Annual Review of Ecological Systems. 23:63-87.

Drake, K.R., and T.D. Whitson. 1989. Control of hoary cress (Cardaria draba (L.) Desv.) on pastures. Page 40 In: Proceedings of the Western Society of Weed Science. Vol. 42. Western Society of Weed Science.

Forgione, H.M. 1993. Limits to the establishment and growth of tree-of-heaven explored (New Jersey). Restoration Management Notes. 11:70-71.

Harrington, T.B. and J.H. Miller. 2005. Effects of application rate, timing, and formulation of glyphosate and triclopyr on control of Chinese privet (Ligustrum sinense). Weed Technology. 19:47-54.

Heisey, R.M. 1990. Allelopathic and herbicidal effects of extracts from tree of heaven (Ailanthus altissima). American Journal of Botany. 77:662-670.

Higgins, S.I., D.M. Richardson, and R.M. Cowling. 1996. Modeling invasive plant spread: the role of plant-environment interactions and model structure. Ecology. 77:2043-2054.

Hoshovsky, M.C. 1988. Element Stewardship Abstract: Ailanthus altissima (tree of heaven). The Nature Conservency. Arlington, VA. Available online:

http://ncweeds.ucdavis.edu/esadocs/documnts/ailaalt.html

Hu, S.Y. 1979. Ailanthus. Arnoldia. 39(2):29-50.

Illick, J.S., and E.F. Brouse. 1926. The ailanthus tree in Pennsylvania. Pennsylvania Department of Forestry and Waters. Bulletin 38. 29pp. 
Knapp, L.B. and C.D. Canham. 2000. Invasion of an old-growth forest in New York by Ailanthus altissima: sapling growth and recruitment in canopy gaps. Journal of the Torrey Botanical Society. 127(4):307-315.

Kochenderfer, J. K; Zedaker, S. M.; Johnson, J. E. [and others]. 2001. Herbicide crop tree release in central West Virginia. Northern Journal of Applied Forestry. 18(2):46-54.

Kowarik, I. 1995. Clonal growth in Ailanthus altissima on a natural site in West Virginia. Journal of Vegetation Science. 6:853-856.

Musil, C.F. 1993. Effects of invasive Australian acacias on the regeneration, growth and nutrient chemistry of South African lowland fynbos. Journal of Applied Ecology. 30:361-372.

Meyer, J.Y. and J. Florence. 1996. Tahiti's native flora endangered by the invasion of Miconia calvascens DC. Journal of Biogeography. 23:775-782.

Le Maitre, D.C., B.W. van Wilgen, R.A. Chapman, and D.H. McKelly. 1996. Invasive species and water resources in the western cape province, South Africa: modeling the consequences of a lack of management. Journal of Applied Ecology. 33:161-172.

Little, E.L. 1979. Checklist of United State Trees (Native and Naturalized). United States Department of Agriculture. Agricultural Handbook No. 541. p.47.

Lym, R.G. and C.G. Messerwmith. 1994. Leafy sprurge (Euphorbia esula) control, forage production, and economic return with fall-applied herbicides. Weed Technology. 11:787-792.

[NRCS] Natural Resources Conservation Service. 1977. Soil Survey of Monongalia and Marion Counties, WV. United State Department of Agriculture - Natural Resources Conservation Service.

Parker, I. M. and S. H. Reichard. 1998. Critical issues in invasion biology for conservation science. In: Fiedler, P.L. and P.M. Kareiva, eds. Conservation biology: for the coming decade. 2nd ed. Chapman and Hall. New York, NY. pp.283-305.

Randal, J.M.; Martinelli, J. 1996. Invasive Plants: Weeds of the Global Garden. Brooklyn, NY: Brooklyn Botanical Gardens. p.27.

[SAS] Statistical Analysis Systems. 2003. SAS Procedures Guide. SAS Version 9.1. Cary, NC: Statistical Analysis Systems Institute.

Schmitz, D.C., D.Simberloff, R.H. Hofstetter, W. Haller and D. Sutton. 1997. The ecological impact of nonindigenous plants. In: Simberloff, D., D.C. Schmitz, and T.C. Brown, eds. Strangers in Paradise: Impact and Management of Nonindigenous Species in Florida,. Island Press. Washington, DC. Pp.39-61

Stenkamp, H.E., and S.L. Chown. 1996. Influence of dense stands of an exotic tree, Prosopis glandulosa Benson, on a savanna dung beetle assemblage in southern Africa. Biological Conservation. 78:305-311.

Udvardy, L. 1998. Classification of adventives dangerous to the Hungarian natural flora. Acta Botanica Hungarica. 41:315-331.

[USDA] United States Department of Agriculture. 1989. Vegetation management in the Appalachian Mountains. United States Department of Agriculture Forest Service. Vol. 1 Management Bulletin R8-MB38. 399pp. 
Vitousek, P. M., H. A. Mooney, J. Lubchenco, and J. M. Melillo. 1997. Human domination of Earth's ecosystems. Science 277:494-499.

Vitousek, P.M. and L.R. Walker. 1989. Biological invasions by Myricacia faya in Hawaii: plant demography, nitrogen fixation, ecosystem effects. Ecological Monographs. 59:247-265.

Walker, B. and W. Steffen. 1997. An overview of the implications of global change for natural and managed terrestrial ecosystems. Conservation Ecology. 1(2):2.

Ware, G.W. 2000. The Pesticide Book, $5^{\text {th }}$ Ed. Fresno, CA: Thomson Publications. 415 pp.

Waterhouse, D.M. and J.E. Mahoney. 1983. Effect of pre-fallowing application of glyphosate on hoary cress (Cardaria draba (L.) Desv.). Australian Weeds. 2:141-143.

Whitson, T.D., A. Mooney, and M. Griswold. 1989. Control of hoary cress (Cardaria draba) with various herbicides. p.39. In: Proceedings of the Western Society of Weed Science. Vol. 42. Western Society of Weed Science.

[WSSA] Weed Science Society of America. 1994. Herbicide Handbook. $7^{\text {th }}$ ed. Champaign, IL: Weed Science Society of America.

Young, J.A., D.E. Palmquist, and R.R. Blank. 1998. The ecology and control of perennial pepperweed (Lepidium latifolium L.). Weed Technology. 12: 402-405.

Table 1--Composition and mean heights of sapling regeneration.

\begin{tabular}{lccc}
\hline Species & Trees per hectare & Abundance & $\begin{array}{c}\text { Mean height } \\
(\mathbf{m})\end{array}$ \\
\hline Ailanthus altissma & 4923 & $66.9 \%$ & 3.64 \\
Acer saccharum & 1246 & $16.9 \%$ & 1.94 \\
Prunus serotina & 328 & $4.5 \%$ & 2.10 \\
Fagus grandifolia & 226 & $3.1 \%$ & 1.99 \\
Liriodendron tulipifera & 190 & $2.6 \%$ & 2.06 \\
Others* & 185 & $2.5 \%$ & 2.26 \\
Fraxinus americana & 174 & $2.4 \%$ & 2.35 \\
Carya tomentosa & 87 & $1.2 \%$ & 1.89 \\
\hline
\end{tabular}

*others include Cornus florida, Ulmus rubra, Nyssa sylvatica, Quercus rubra, Quercus alba, Quercus velutina, and Quercus prinus 
Table 2-- Frequency of woody and herbaceous understory species

\begin{tabular}{|c|c|c|}
\hline Common Name & Scientific Name & Frequency $(\%)$ \\
\hline blackberry & Rubus spp. & 91 \\
\hline violets & Viola spp. & 89 \\
\hline grasses* & Poaceae & 79 \\
\hline speicebush & Lindera benzoin & 78 \\
\hline Christmas fern & Polystichum acrostichoides & 66 \\
\hline Virginia creeper & Parthenocissus quinquefolia & 65 \\
\hline yellow bedstraw & Galium verum & 62 \\
\hline pokeberry & Phytolacca americana & 61 \\
\hline black cohosh & Cimicifuga racemosa & 53 \\
\hline May apple & Podophyllum peltatum & 53 \\
\hline greenbriar & Smilax spp. & 50 \\
\hline jack in the pulpit & Arisaema triphyllum & 47 \\
\hline garlic mustard & Alliaria petiolata & 40 \\
\hline invasive fern & Dennstaedtia punctilobula & 38 \\
\hline grape & Vitus spp. & 37 \\
\hline tatarian honeysuckle & Lonicera tatarica & 34 \\
\hline stinging nettle & Urtica dioica & 32 \\
\hline multiflora rose & Rosa multiflora & 30 \\
\hline witch hazel & Hamamelis virginiana & 27 \\
\hline trilium & Trillium spp. & 26 \\
\hline godenrod & Solidago spp. & 25 \\
\hline viburnums & Caprifoliaceae spp. & 24 \\
\hline poison ivy & Toxicodenron radicans & 19 \\
\hline burdock & Arctium spp. & 18 \\
\hline sweet clover & Trifolium spp. & 17 \\
\hline elderberry & Sambucus canadensis & 15 \\
\hline solomon seal & Polygonatum biflorum & 14 \\
\hline cinquefoil & Potentilla simplex & 11 \\
\hline thistle & Cirsium discolor & 9 \\
\hline hog peanut & Amphicaraea bracteata & 9 \\
\hline Devil's walkingstick & Aralia spinosa & 7 \\
\hline jewelweed & Impatiens capensis & 4 \\
\hline
\end{tabular}

*identified grasses consist of Agrostis, Dactylis, Danthonia, Festuca and, Poa spp. 
Table 3-- Seedling composition at study site on Crawford Tree Farm.

\begin{tabular}{|c|c|c|c|}
\hline Species & & $\begin{array}{c}\text { Seedlings per } \\
\text { hectare }\end{array}$ & $\begin{array}{c}\text { Abundance } \\
(\%) \\
\end{array}$ \\
\hline red maple & Acer saccharum & 28,780 & 72.00 \\
\hline yellow-poplar & Liriodendron tulipifera & 3,036 & 7.60 \\
\hline slippery elm & Ulmus rubra & 2,681 & 6.71 \\
\hline black cherry & Prunus serotina & 1,550 & 3.88 \\
\hline tree-of-heaven & Ailanthus altissma & 921 & 2.30 \\
\hline white ash & Fraxinus americana & 824 & 2.06 \\
\hline American beech & Fagus grandifolia & 694 & 1.74 \\
\hline mockernut hickory & Carya tomentosa & 598 & 1.49 \\
\hline flowering dogwood & Cornus florida & 468 & 1.17 \\
\hline black oak & Quercus velutina & 210 & 0.53 \\
\hline red oak & Quercus rubra & 65 & 0.16 \\
\hline white oak & Quercus alba & 65 & 0.16 \\
\hline sassafras & Sassafras albidum & 65 & 0.16 \\
\hline hawthorn & Crataegus spp. & 16 & 0.04 \\
\hline
\end{tabular}

Table 4-- Comparison of mean monthly precipitation from treatment year (observed) and the mean of eight previous years

\begin{tabular}{|c|c|c|c|c|c|}
\hline & \multicolumn{3}{|c|}{ Precipitation (cm) } & \multicolumn{2}{|c|}{ Mean Temp. $\left({ }^{\circ} \mathrm{C}\right)$} \\
\hline & Mean & Observed & & Mean & Observed \\
\hline Apr-04 & 7.01 & 9.83 & & 11.91 & 11.24 \\
\hline May-04 & 11.40 & 10.77 & & 16.27 & 19.23 \\
\hline Jun-04 & 7.82 & 10.92 & & 20.11 & 20.07 \\
\hline Jul-04 & 11.35 & 8.46 & & 22.50 & 22.16 \\
\hline Aug-04 & 6.48 & 14.88 & $*$ & 22.05 & 20.84 \\
\hline Sep-04 & 5.79 & 11.10 & & 18.18 & 19.24 \\
\hline Oct-04 & 4.57 & 8.61 & $*$ & 12.24 & 12.69 \\
\hline Nov-04 & 6.50 & 8.76 & & 6.83 & 8.74 \\
\hline Dec-04 & 4.83 & 4.70 & & 1.94 & 2.15 \\
\hline Jan-05 & 6.48 & 15.06 & $*$ & -0.44 & 0.92 \\
\hline Feb-05 & 4.75 & 6.22 & & 1.73 & 2.20 \\
\hline Mar-05 & 6.27 & 10.92 & & 5.58 & 3.47 \\
\hline
\end{tabular}

$*$ denotes significant difference $(\mathrm{p}<0.05)$ 
Figure 1-- Average weekly diameter and height growth increment during the growing season of the treatment year

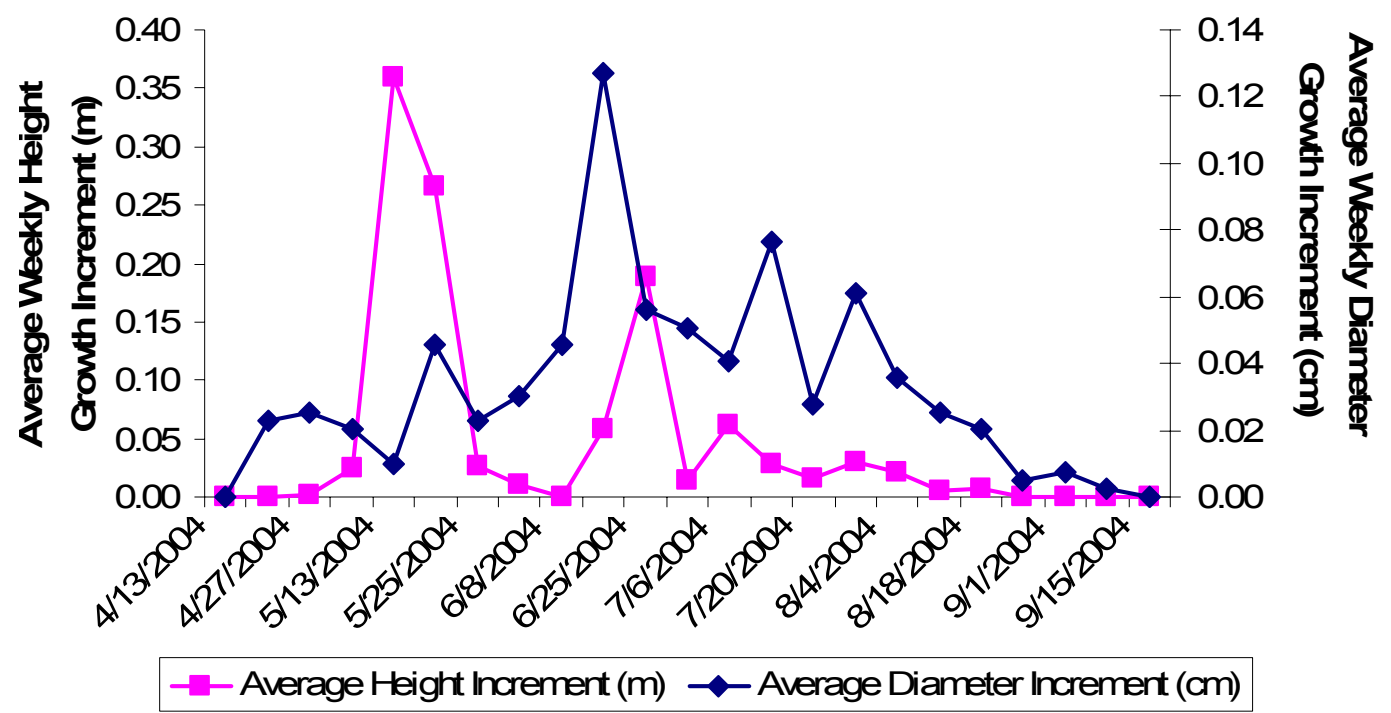

Figure 2-- Weekly average diameter growth incremtent and weekly total precipitation were correlated

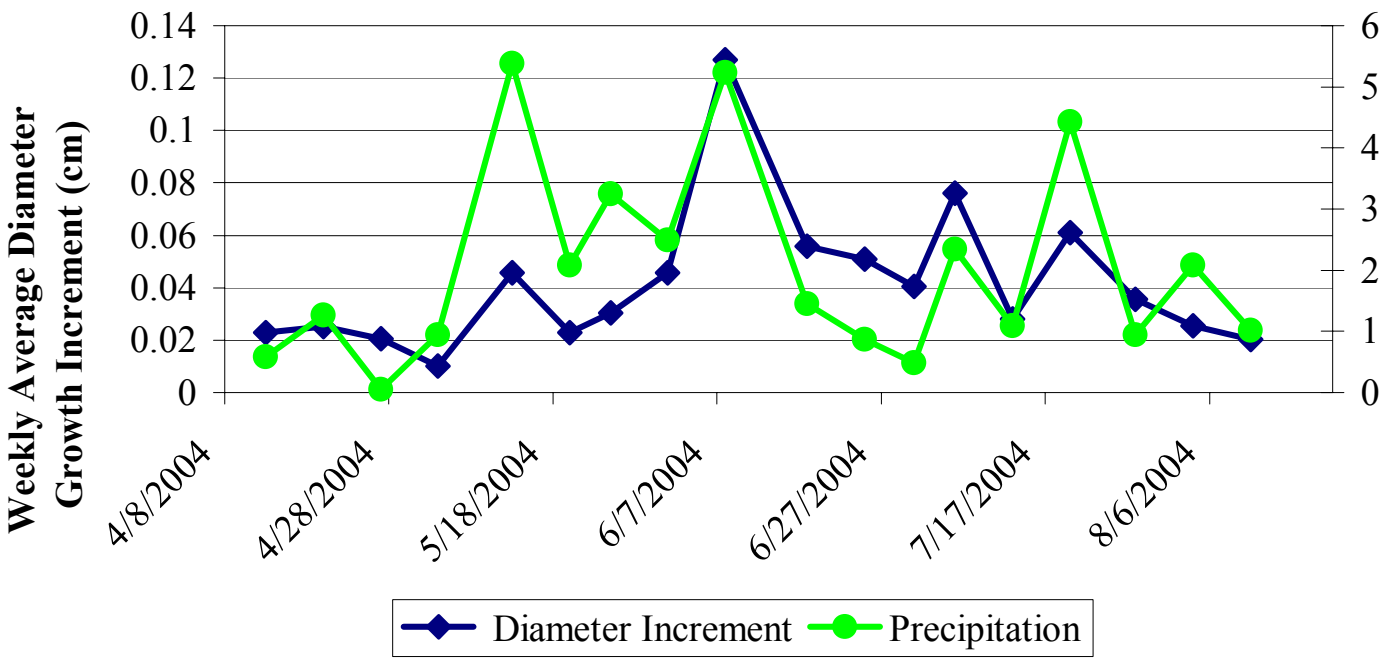


Figure 3-- Percent of treated trees with sprouting by week. Weeks with same letter are not significantly different $(\mathbf{p}<0.05)$

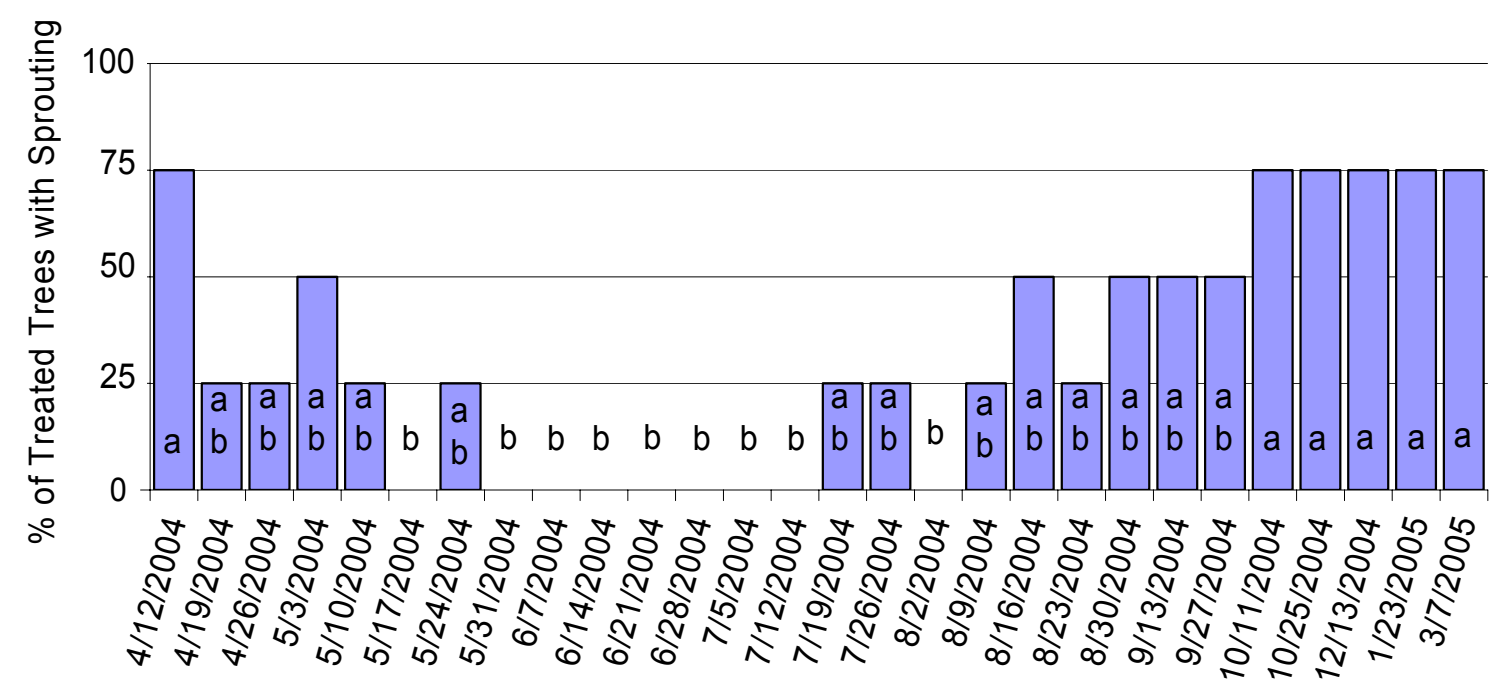

Figure 4-- Percent treated trees with sprouting 12MAT was lower when diameter increment was higher

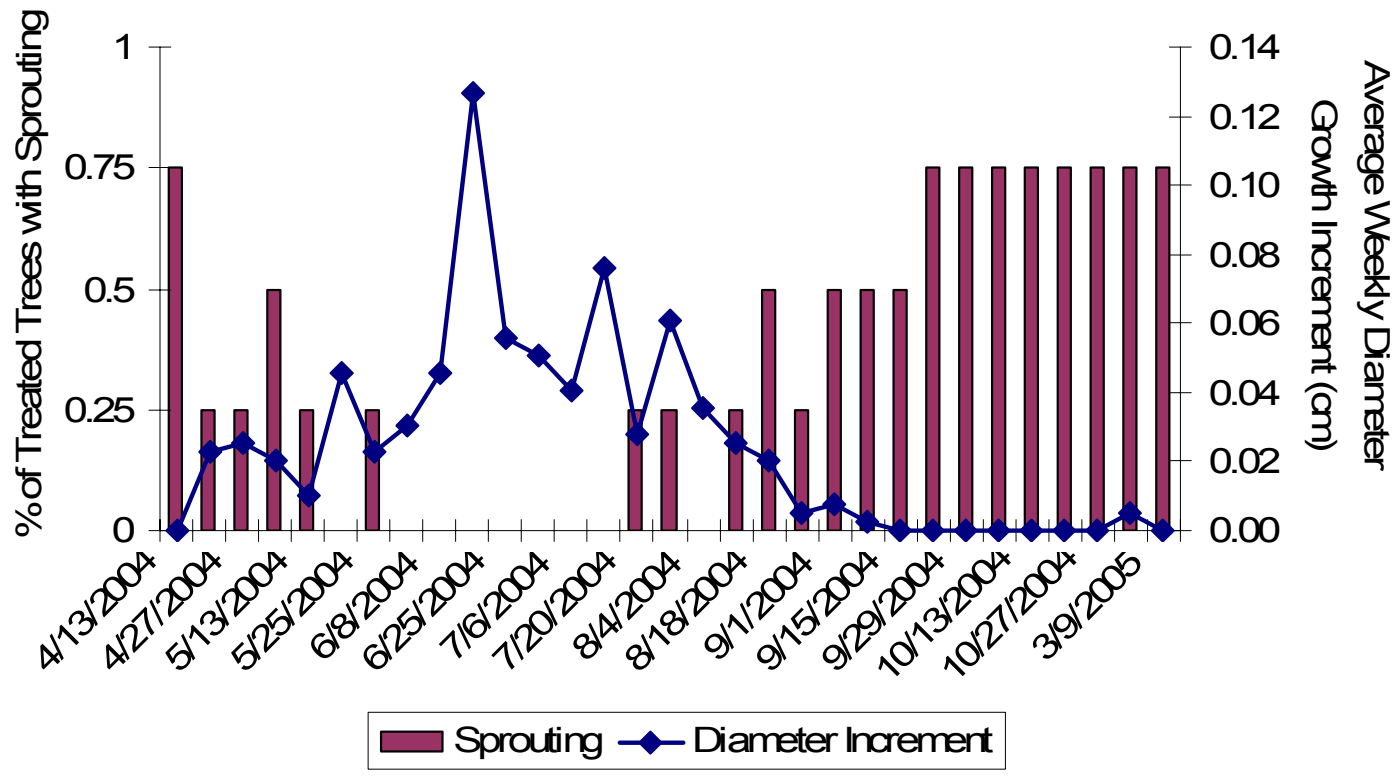

